NIST NCSTAR 1-1G

Federal Building and Fire Safety Investigation of the World Trade Center Disaster

\title{
Amendments to the Fire Protection and Life Safety Provisions of the New York City Building Code by Local Laws Adopted While World Trade Center 1, 2, and 7 Were in Use
}



Federal Building and Fire Safety Investigation of the World Trade Center Disaster

\section{Amendments to the Fire Protection and Life Safety Provisions of the New York City Building Code by Local Laws Adopted While World Trade Center 1, 2, and 7 Were in Use}

Joseph C. Razza

Raymond A. Grill

Rolf Jensen \& Associates, Inc.

September 2005

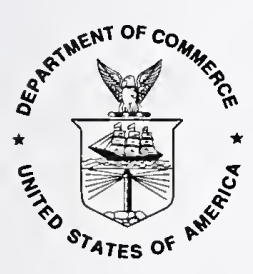

U.S. Department of Commerce Carlos M. Gutierrez, Secretary 


\section{Disclaimer No. 1}

Certain commercial entities, equipment, products, or materials are identified in this document in order to describe a procedure or concept adequately or to trace the history of the procedures and practices used. Such identification is not intended to imply recommendation, endorsement, or implication that the entities, products, materials, or equipment are necessarily the best available for the purpose. Nor does such identification imply a finding of fault or negligence by the National Institute of Standards and Technology.

\section{Disclaimer No. 2}

The policy of NIST is to use the International System of Units (metric units) in all publications. In this document, however, units are presented in metric units or the inch-pound system, whichever is prevalent in the discipline.

\section{Disclaimer No. 3}

Pursuant to section 7 of the National Construction Safety Team Act, the NIST Director has determined that certain evidence received by NIST in the course of this Investigation is "voluntarily provided safety-related information" that is "not directly related to the building failure being investigated" and that "disclosure of that information would inhibit the voluntary provision of that type of information" (15 USC 7306c).

In addition, a substantial portion of the evidence collected by NIST in the course of the Investigation has been provided to NIST under nondisclosure agreements.

\section{Disclaimer No. 4}

NIST takes no position as to whether the design or construction of a WTC building was compliant with any code since, due to the destruction of the WTC buildings, NIST could not verify the actual (or as-built) construction, the properties and condition of the materials used, or changes to the original construction made over the life of the buildings. In addition, NIST could not verify the interpretations of codes used by applicable authorities in determining compliance when implementing building codes. Where an Investigation report states whether a system was designed or installed as required by a code provision, NIST has documentary or anecdotal evidence indicating whether the requirement was met, or NIST has independently conducted tests or analyses indicating whether the requirement was met.

\section{Use in Legal Proceedings}

No part of any report resulting from a NIST investigation into a structural failure or from an investigation under the National Construction Safety Team Act may be used in any suit or action for damages arising out of any matter mentioned in such report (15 USC 281a; as amended by P.L. 107-231).

National Institute of Standards and Technology National Construction Safety Team Act Report 1-1G Natl. Inst. Stand. Technol. Natl. Constr. Sfty. Tm. Act Rpt. 1-1G, 64 pages (September 2005) CODEN: NSPUE2

\section{U.S. GOVERNMENT PRINTING OFFICE WASHINGTON: 2005}

For sale by the Superintendent of Documents, U.S. Government Printing Office Internet: bookstore.gpo.gov — Phone: (202) 512-1800 — Fax: (202) 512-2250 Mail: Stop SSOP, Washington, DC 20402-0001 


\section{ABSTRACT}

This report was prepared to support the analysis of building and fire codes and practices of the National Institute of Standards and Technology (N1ST) World Trade Center (WTC) Investigation. This report supports the objective of documenting the rcquirements that governed the design and construction of WTC 1, 2, and 7 .

The purpose of this report is to provide an evolution of the life safety provisions of the Building Code of the City of New York (BCNYC) since the design of WTC 1 and WTC 2, including retroactive provisions for existing high-rise office towers. It has been previously established that WTC 1 and WTC 2 were designed and constructed in accordance with the BCNYC as enacted by Local Law No. 76 for the year 1968, effective December 6, 1968.

The evolution of the BCNYC begins with a brief history of the Building Code prior to 1968 and reviews the various local laws that have amended fire protection and life safety provisions of the Code from 1968 until the collapse of the WTC towers on September 11, 2001.

Keywords: Administrative code, building code, compartmentation, elevators, emergency power, fire alarm, fire protection, fire safety, fire sprinklers, high-rise buildings, inspections, interior finish, life safety, means of egress, pressurization, venting, voice communication, World Trade Center. 
This page intentionally left blank. 


\section{TABLE OF CONTENTS}

Abstract iii

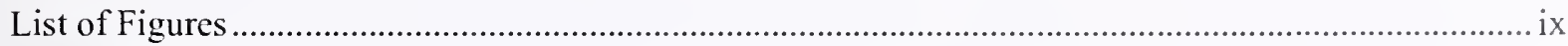

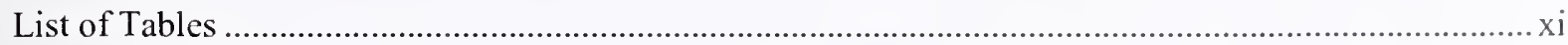

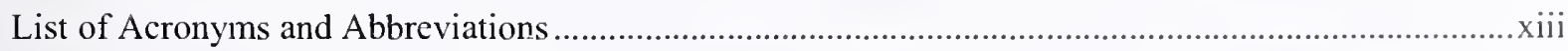

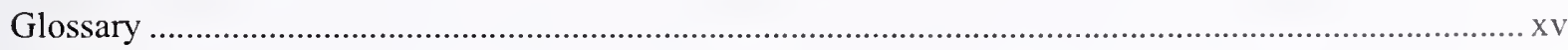

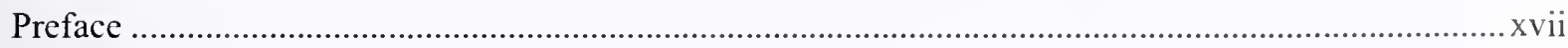

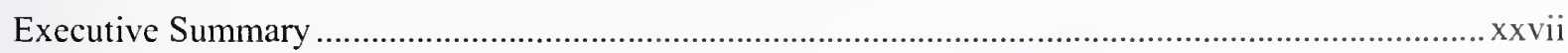

Chapter 1

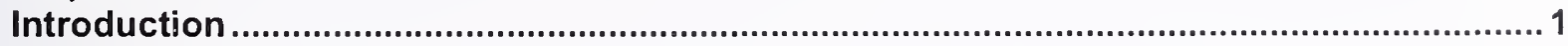

Chapter 2

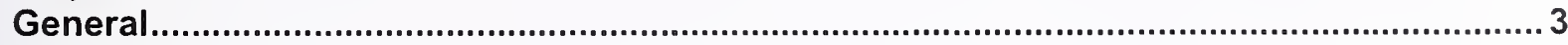

2.1 Local Laws Containing Fire Protection/Life Safety Provisions ................................................. 3

2.2 Effective Dates of Local Laws Amending the Building Code................................................... 4

\section{Chapter 3}

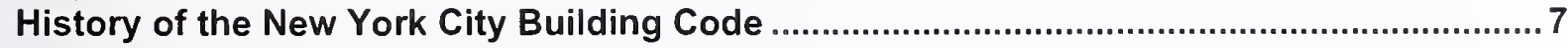

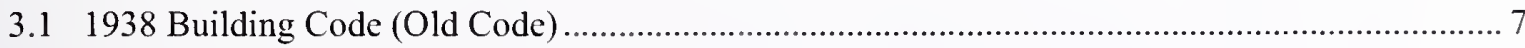

3.21968 Building Code (Then Current Code).............................................................................. 7

\section{Chapter 4}

Evolution of Building Code since 1968..................................................................9

4.11970 - Local Law No. 54, Powers and Duties of the Department of Buildings.......................... 9

4.21973 - Local Law No. 5, Fire Safety Requirements in Certain Office Buildings ...................... 10

4.2.1 Fire Safety in Office Buildings............................................................................ 10

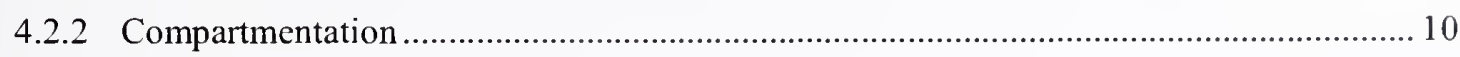

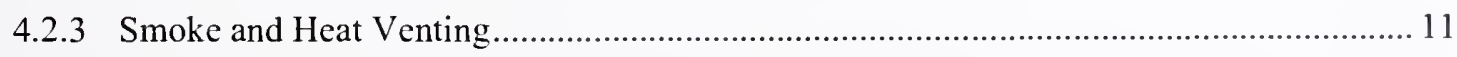

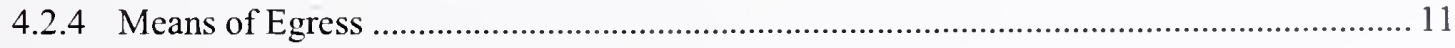

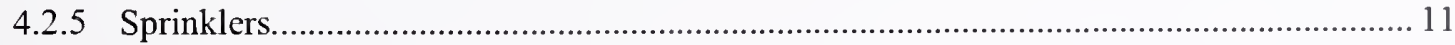

4.2.6 Interior Fire Alarm Signal and Voice Communication Systems .................................. 12

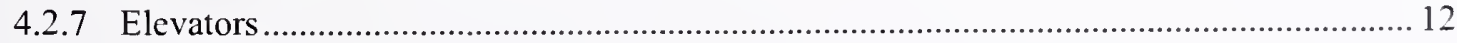

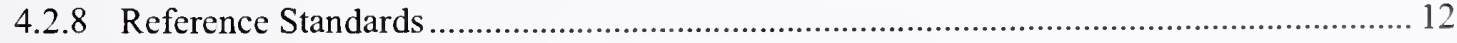

4.31975 - Local Law No. 26, Fire Safety in Office Buildings ..................................................... 13 
4.4 1976 - Local Law No. 55, Inspection of Sprayed-On Fire Protection of Structural Members ..... 13

4.51978 - Local Law No. 33, Fire Wardens in Office Buildings ............................................. 14

4.6 1978 - Local Law No. 41, Fire Protection for Places of Assembly......................................... 14

4.71979 - Local Law No. 84, Fire Safety Pressurization in Office Buildings................................ 15

4.81979 - Local Law No. 86, Revised Compliance Dates for Local Law No. 5/1973...................... 16

4.91984 - Local Law No. 16, Fire Safety Requirements in Certain Buildings ............................... 17

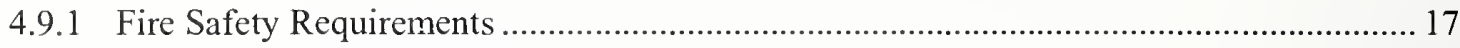

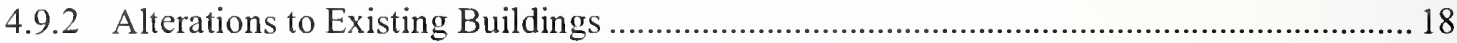

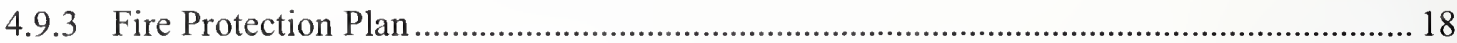

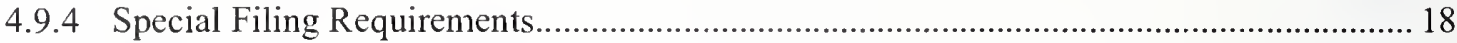

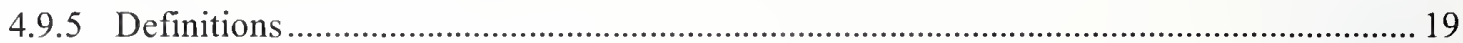

4.9.6 Height and Area Limitations ............................................................................... 19

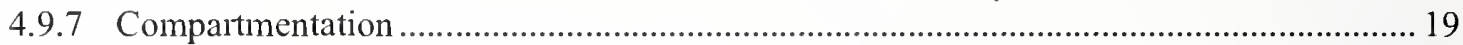

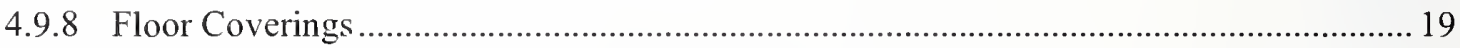

4.9.9 Smoke Protection for Elevators and Escalators........................................................ 20

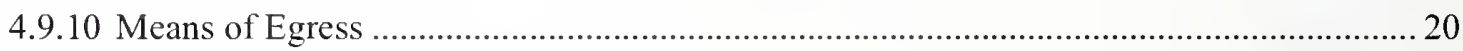

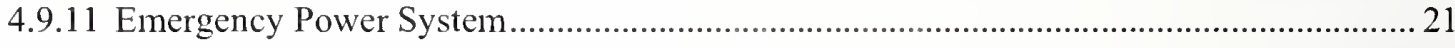

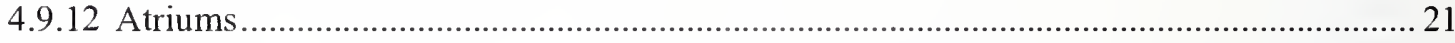

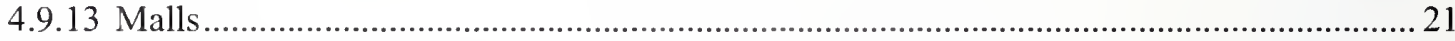

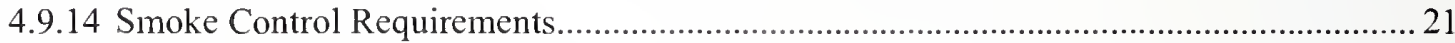

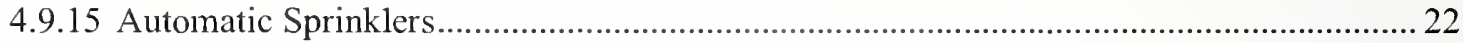

4.9.16 Fire Alarm and Communication Systems................................................................... 22

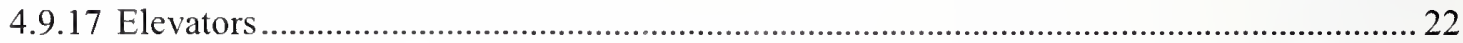

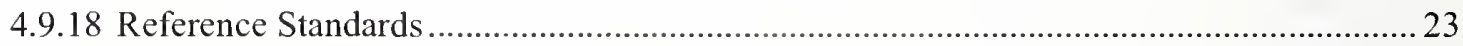

4.101985 - Laws of New York State, Renumbering of New York City Administrative Code ............24

4.111987 - Local Law No. 16, Fire Alarm Systems and Reference Standards ................................ 25

\section{Chapter 5}

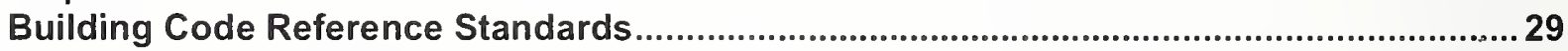

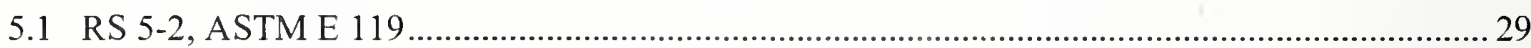

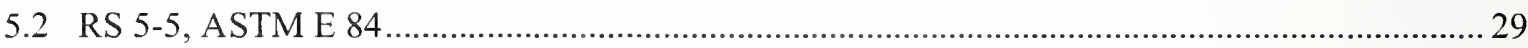

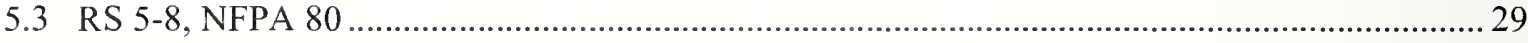

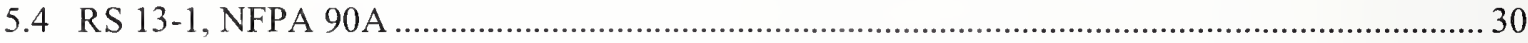

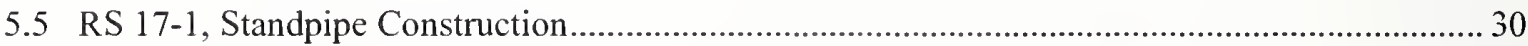

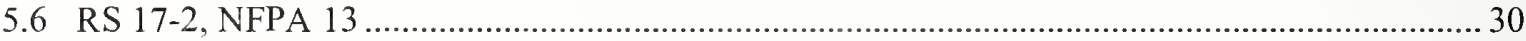


5.7 RS 17-3, Fire Alarm and Extinguishing Systems .......................................................... 31

5.8 RS 17-3A, Class E Fire Alarm Systems .................................................................... 31

5.9 RS 17-3B, Modified Class E Fire Alarm Systems.............................................................. 31

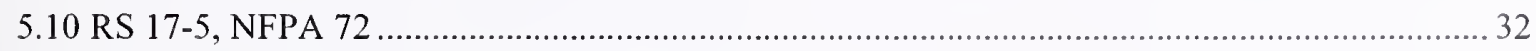

5.11 RS 18-1, American National Standards Institute A17.1 .................................................. 32

\section{Chapter 6}

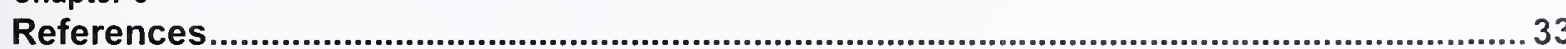


This page intentionally left blank. 


\section{LIST OF FIGURES}

Figure $\mathrm{P}-1$. The eight projects in the federal building and fire safety investigation of the WTC disaster. xix 
This page intentionally left blank. 


\section{LIST OF TABLES}

Table P-1. Federal building and fire safety investigation of the WTC disaster. ...............................

Table P-2. Public meetings and briefings of the WTC Investigation. .......................................... $\mathrm{xxi}$

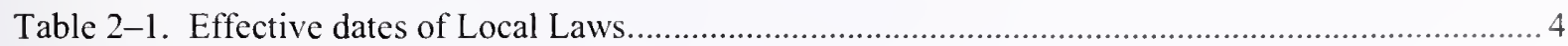


This page intentionally left blank. 


\section{LIST OF ACRONYMS AND ABBREVIATIONS}

\section{Acronyms}

$\begin{array}{ll}\text { ASTM } & \text { ASTM International } \\ \text { BSA } & \text { New York City Board of Standards and Appeals } \\ \text { BCNYC } & \text { Building Code of the City of New York (Local Law No. 76) } \\ \text { LL } & \text { Local Law to amend the Administrative Code of the City of New York } \\ \text { NFPA } & \text { National Fire Protection Association } \\ \text { NIST } & \text { National Institute of Standards and Technology } \\ \text { RS } & \text { Reference Standard to the Building Code of the City of New York } \\ \text { WTC } & \text { World Trade Center } \\ \text { WTC 1 } & \text { World Trade Center 1 (North Tower) } \\ \text { WTC 2 } & \text { World Trade Center 2 (South Tower) } \\ \text { WTC 7 } & \text { World Trade Center } 7\end{array}$

\section{Abbreviations}

${ }^{\circ} \mathrm{F}$

degrees Fahrenheit

cfm

cubic foot per minute

$\mathrm{ft}$

foot

$\mathrm{ft}^{2}$

square foot

h

hour

$\min$

minute 
This page intentionally left blank. 


\section{GLOSSARY}

active fire protection - A means to help prevent the loss of life and property from fire by extinguishing, suppressing, or controlling a firc through functional systems. Sprinkler systcms, fire alarm systems, and smoke control systems are examples of active fire protection.

area of refuge - A floor area to which egress is made through a horizontal exit or supplemental vertical exit.

combustible - A material that is not determined to be noncombustible.

damper - A device installed in heating, ventilating, and air conditioning ductwork used to prevent the spread of fire and/or smoke. Dampers are provided to maintain a fire resistance rating of the assembly being penetrated.

detector - An initiation device that automatically detects a change in state, such as presence of smoke, high temperature, or abnormal rate of temperature rise.

fire alarm system - A system, automatic or manual, arranged to give a signal indicating a fire emergency and initiate the appropriate response.

fire resistance rating - The time in hours that materials or their assemblies will withstand fire exposure as determined by a fire test.

fireproofing - Materials or assemblies used to provide a fire resistance rating to a building component.

firestop - A solid or compact, tight closure to retard the spread of flames or hot gases within concealed spaces.

initiation device - A system component that originates a change-in-state signal in the fire alarm system. An initiation device begins the life safety processes, such as evacuation; heating, ventilating, and air conditioning shut down; elevator recall; etc.

manual fire alarm box - A manually operated initiation device that originates a change-in-state signal in the fire alarm system.

means of egress - A continuous and unobstructed path of vertical and horizontal travel from any point in a building to a public way. The means of egress consists of the exit access, the exit, and the exit discharge.

noncombustible - A material that, in the form in which it is used in construction, will not ignite and burn when subjected to fire. However, any material which liberates flammable gas when heated to any temperature up to $1,380^{\circ} \mathrm{F}$ for $5 \mathrm{~min}$ shall not be considered noncombustible. 
notification appliance - A fire alarm system component such as a bell, horn, speaker, or strobe that provides audible, tactile, or visible outputs, or any combination thereof.

passive fire protection - Fire protection features that are incorporated into the building construction or building materials that do not rely on active fire protection methods to limit fire ignition, fire growth, or material failure. Fire separations and divisions, sprayed-on fire proofing, and enclosing structural members with noncombustible materials are examples of passive fire protection.

smoke and heat venting - A process used to move products of combustion to the outdoor air. 


\section{Preface}

\section{Genesis of This Investigation}

Immediately following the terrorist attack on the World Trade Center (WTC) on Scptcmber 11, 2001, the Federal Emergency Management Agency (FEMA) and the American Society of Civil Engineers began planning a building performance study of the disaster. The week of October 7, as soon as the rescue and search efforts ceased, the Building Performance Study Team went to the site and began its asscssment. This was to be a brief effort, as the study team consisted of experts who largely volunteered their time away from their other professional commitments. The Building Performance Study Team issued its report in May 2002, fulfilling its goal "to determine probable failure mechanisms and to identify areas of future investigation that could lead to practical measures for improving the damage resistance of buildings against such unforeseen events."

On August 21, 2002, with funding from the U.S. Congress through FEMA, the National Institute of Standards and Technology (NIST) announced its building and fire safety investigation of the WTC disaster. On October 1, 2002, the National Construction Safety Team Act (Public Law 107-231), was signed into law. The NIST WTC Investigation was conducted under the authority of the National Construction Safety Team Act.

The goals of the investigation of the WTC disaster were:

- To investigate the building construction, the materials used, and the technical conditions that contributed to the outcome of the WTC disaster.

- To serve as the basis for:

- Improvements in the way buildings are designed, constructed, maintained, and used;

- Improved tools and guidance for industry and safety officials;

- Recommended revisions to current codes, standards, and practices; and

- Improved public safety.

The specific objectives were:

1. Determine why and how WTC 1 and WTC 2 collapsed following the initial impacts of the aircraft and why and how WTC 7 collapsed;

2. Determine why the injuries and fatalities were so high or low depending on location, including all technical aspects of fire protection, occupant behavior, evacuation, and emergency response;

3. Determine what procedures and practices were used in the design, construction, operation, and maintenance of WTC 1, 2, and 7; and

4. Identify, as specifically as possible, areas in current building and fire codes, standards, and practices that warrant revision. 
NIST is a nonregulatory agency of the U.S. Department of Commerce's Technology Administration. The purpose of NIST investigations is to improve the safety and structural integrity of buildings in the United States, and the focus is on fact finding. NIST investigative teams are authorized to assess building performance and emergency response and evacuation procedures in the wake of any building failure that has resulted in substantial loss of life or that posed significant potential of substantial loss of life. NIST does not have the statutory authority to make findings of fault nor negligence by individuals or organizations. Further, no part of any report resulting from a NIST investigation into a building failure or from an investigation under the National Construction Safety Team Act may be used in any suit or action for damages arising out of any matter mentioned in such report (15 USC 281a, as amended by Public Law 107-231).

\section{Organization of the Investigation}

The National Construction Safety Team for this Investigation, appointed by the then NIST Director, Dr. Arden L. Bement, Jr., was led by Dr. S. Shyam Sunder. Dr. William L. Grosshandler served as Associate Lead Investigator, Mr. Stephen A. Cauffman served as Program Manager for Administration, and Mr. Harold E. Nelson served on the team as a private sector expert. The Investigation included eight interdependent projects whose leaders comprised the remainder of the team. A detailed description of each of these eight projects is available at http://wtc.nist.gov. The purpose of each project is summarized in Table $\mathrm{P}-1$, and the key interdependencies among the projects are illustrated in Fig. $\mathrm{P}-1$.

Table P-1. Federal building and fire safety investigation of the WTC disaster.

\begin{tabular}{|c|c|}
\hline Technical Area and Project Leader & Project Purpose \\
\hline $\begin{array}{l}\text { Analysis of Building and Fire Codes and } \\
\text { Practices; Project Leaders: Dr. H. S. Lew } \\
\text { and Mr. Richard W. Bukowski }\end{array}$ & $\begin{array}{l}\text { Document and analyze the code provisions, procedures, and } \\
\text { practices used in the design, construction, operation, and } \\
\text { maintenance of the structural, passive fire protection, and } \\
\text { emergency access and evacuation systems of WTC } 1,2 \text {, and } 7 \text {. }\end{array}$ \\
\hline $\begin{array}{l}\text { Baseline Structural Performance and } \\
\text { Aircraft Impact Damage Analysis; Project } \\
\text { Leader: Dr. Fahim H. Sadek }\end{array}$ & $\begin{array}{l}\text { Analyze the baseline performance of WTC } 1 \text { and WTC } 2 \text { under } \\
\text { design, service, and abnormal loads, and aircraft impact damage on } \\
\text { the structural, fire protection, and egress systems. }\end{array}$ \\
\hline $\begin{array}{l}\text { Mechanical and Metallurgical Analysis of } \\
\text { Structural Steel; Project Leader: Dr. Frank } \\
\text { W. Gayle }\end{array}$ & $\begin{array}{l}\text { Determine and analyze the mechanical and metallurgical properties } \\
\text { and quality of steel, weldments, and connections from steel } \\
\text { recovered from WTC } 1,2 \text {, and } 7 \text {. }\end{array}$ \\
\hline $\begin{array}{l}\text { Investigation of Active Fire Protection } \\
\text { Systems; Project Leader: Dr. David } \\
\text { D. Evans; Dr. William Grosshandler }\end{array}$ & $\begin{array}{l}\text { Investigate the performance of the active fire protection systems in } \\
\text { WTC } 1,2 \text {, and } 7 \text { and their role in fire control, emergency response, } \\
\text { and fate of occupants and responders. }\end{array}$ \\
\hline $\begin{array}{l}\text { Reconstruction of Thermal and Tenability } \\
\text { Environment; Project Leader: Dr. Richard } \\
\text { G. Gann }\end{array}$ & $\begin{array}{l}\text { Reconstruct the time-evolving temperature, thermal environment, } \\
\text { and smoke movement in WTC } 1,2 \text {, and } 7 \text { for use in evaluating the } \\
\text { structural performance of the buildings and behavior and fate of } \\
\text { occupants and responders. }\end{array}$ \\
\hline $\begin{array}{l}\text { Structural Fire Response and Collapse } \\
\text { Analysis; Project Leaders: Dr. John } \\
\text { L. Gross and Dr. Therese P. McAllister }\end{array}$ & $\begin{array}{l}\text { Analyze the response of the WTC towers to fires with and without } \\
\text { aircraft damage, the response of WTC } 7 \text { in fires, the performance } \\
\text { of composite steel-trussed floor systems, and determine the most } \\
\text { probable structural collapse sequence for WTC } 1,2 \text {, and } 7 \text {. }\end{array}$ \\
\hline $\begin{array}{l}\text { Occupant Behavior, Egress, and Emergency } \\
\text { Communications; Project Leader: Mr. Jason } \\
\text { D. Averill }\end{array}$ & $\begin{array}{l}\text { Analyze the behavior and fate of occupants and responders, both } \\
\text { those who survived and those who did not, and the performance of } \\
\text { the evacuation system. }\end{array}$ \\
\hline $\begin{array}{l}\text { Emergency Response Technologies and } \\
\text { Guidelines; Project Leader: Mr. J. Randall } \\
\text { Lawson }\end{array}$ & $\begin{array}{l}\text { Document the activities of the emergency responders from the time } \\
\text { of the terrorist attacks on WTC } 1 \text { and WTC } 2 \text { until the collapse of } \\
\text { WTC } 7 \text {, including practices followed and technologies used. }\end{array}$ \\
\hline
\end{tabular}




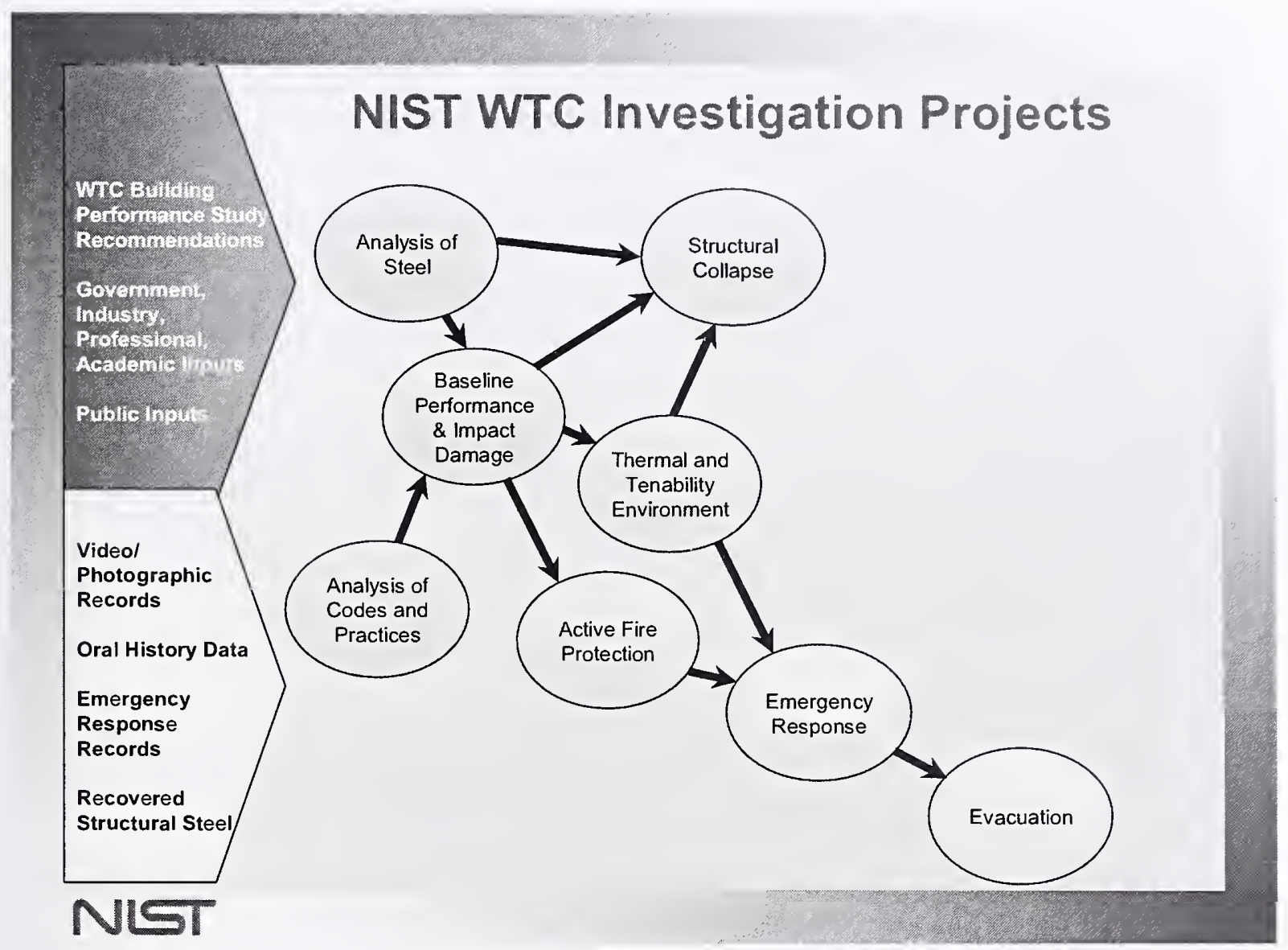

Figure P-1. The eight projects in the federal building and fire safety investigation of the WTC disaster.

\section{National Construction Safety Team Advisory Committee}

The NIST Director also established an advisory committee as mandated under the National Construction Safety Team Act. The initial members of the committee were appointed following a public solicitation. These were:

- Paul Fitzgerald, Executive Vice President (retired) FM Global, National Construction Safety Team Advisory Committee Chair

- John Barsom, President, Barsom Consulting, Ltd.

- John Bryan, Professor Emeritus, University of Maryland

- David Collins, President, The Preview Group, Inc.

- Glenn Corbett, Professor, John Jay College of Criminal Justice

- Philip DiNenno, President, Hughes Associates, Inc. 
- Robert Hanson, Professor Emeritus, University of Michigan

- Charles Thornton, Co-Chairman and Managing Principal, The Thornton-Tomasetti Group, Inc.

- Kathleen Tierney, Director, Natural Hazards Research and Applications Information Center, University of Colorado at Boulder

- Forman Williams, Director, Center for Energy Research, University of California at San Diego

This National Construction Safety Team Advisory Committee provided technical advice during the Investigation and commentary on drafts of the Investigation reports prior to their public release. NIST has benefited from the work of many people in the preparation of these reports, including the National Construction Safety Tcam Advisory Committee. The content of the reports and recommendations, however, are solely the responsibility of NIST.

\section{Public Outreach}

During the course of this Investigation, NIST held public briefings and meetings (listed in Table P-2) to solicit input from the public, present preliminary findings, and obtain comments on the direction and progress of the Investigation from the public and the Advisory Committee.

NIST maintained a publicly accessible Web site during this Investigation at http://wtc.nist.gov. The site contained extensive information on the background and progress of the Investigation.

\section{NIST's WTC Public-Private Response Plan}

The collapse of the WTC buildings has led to broad reexamination of how tall buildings are designed, constructed, maintained, and used, especially with regard to major events such as fires, natural disasters, and terrorist attacks. Reflecting the enhanced interest in effecting necessary change, NIST, with support from Congress and the Administration, has put in place a program, the goal of which is to develop and implement the standards, technology, and practices needed for cost-effective improvements to the safety and security of buildings and building occupants, including evacuation, emergency response procedures, and threat mitigation.

The strategy to meet this goal is a three-part NIST-led publie-private response program that includes:

- A federal building and fire safety investigation to study the most probable factors that contributed to post-aircraft impact collapse of the WTC towers and the 47-story WTC 7 building, and the associated evacuation and emergency response experience.

- A research and development (R\&D) program to (a) facilitate the implementation of recommendations resulting from the WTC Investigation, and (b) provide the technical basis for cost-effective improvements to national building and fire codes, standards, and practices that enhance the safety of buildings, their occupants, and emergency responders. 
Table P-2. Public meetings and briefings of the WTC Investigation.

\begin{tabular}{|c|c|c|}
\hline Date & Location & Principal Agenda \\
\hline June 24,2002 & New York City, NY & $\begin{array}{l}\text { Public meeting: Public comments on the Draft Plan for the } \\
\text { pending WTC Investigation. }\end{array}$ \\
\hline August 21,2002 & Gaithersburg, MD & Media briefing announcing the formal start of the Investigation. \\
\hline December 9, 2002 & Washington, DC & $\begin{array}{l}\text { Media briefing on release of the Public Updute and NIST request } \\
\text { for photographs and videos. }\end{array}$ \\
\hline April 8, 2003 & New York City, NY & $\begin{array}{l}\text { Joint public forum with Columbia University on first-person } \\
\text { interviews. }\end{array}$ \\
\hline April 29-30, 2003 & Gaithersburg, MD & $\begin{array}{l}\text { NCST Advisory Committee meeting on plan for and progress on } \\
\text { WTC Investigation with a public comment session. }\end{array}$ \\
\hline May 7,2003 & New York City, NY & Media briefing on release of May 2003 Progress Report. \\
\hline August $26-27,2003$ & Gaithersburg, MD & $\begin{array}{l}\text { NCST Advisory Committee meeting on status of the WTC } \\
\text { investigation with a public comment session. }\end{array}$ \\
\hline September 17,2003 & New York City, NY & $\begin{array}{l}\text { Media and public briefing on initiation of first-person data } \\
\text { collection projects. }\end{array}$ \\
\hline December 2-3, 2003 & Gaithersburg, MD & $\begin{array}{l}\text { NCST Advisory Committee meeting on status and initial results } \\
\text { and release of the Public Update with a public comment session. }\end{array}$ \\
\hline February 12,2004 & New York City, NY & $\begin{array}{l}\text { Public meeting on progress and preliminary findings with public } \\
\text { comments on issues to be considered in formulating final } \\
\text { recommendations. }\end{array}$ \\
\hline June 18,2004 & New York City, NY & Media/public briefing on release of June 2004 Progress Report. \\
\hline June 22-23, 2004 & Gaithersburg, MD & $\begin{array}{l}\text { NCST Advisory Committee meeting on the status of and } \\
\text { preliminary findings from the WTC Investigation with a public } \\
\text { comment session. }\end{array}$ \\
\hline August 24,2004 & Northbrook, IL & $\begin{array}{l}\text { Public viewing of standard fire resistance test of WTC floor } \\
\text { system at Underwriters Laboratories, Inc. }\end{array}$ \\
\hline October $19-20,2004$ & Gaithersburg, MD & $\begin{array}{l}\text { NCST Advisory Committee meeting on status and near complete } \\
\text { set of preliminary findings with a public comment session. }\end{array}$ \\
\hline November 22,2004 & Gaithersburg, MD & $\begin{array}{l}\text { NCST Advisory Committee discussion on draft annual report to } \\
\text { Congress, a public comment session, and a closed session to } \\
\text { discuss pre-draft recommendations for WTC Investigation. }\end{array}$ \\
\hline April 5, 2005 & New York City, NY & $\begin{array}{l}\text { Media and public briefing on release of the probable collapse } \\
\text { sequence for the WTC towers and draft reports for the projects on } \\
\text { codes and practices, evacuation, and emergency response. }\end{array}$ \\
\hline June 23,2005 & New York City, NY & $\begin{array}{l}\text { Media and public briefing on release of all draft reports for the } \\
\text { WTC towers and draft recommendations for public comment. }\end{array}$ \\
\hline $\begin{array}{l}\text { September } 12-13 \text {, } \\
2005\end{array}$ & Gaithersburg, MD & $\begin{array}{l}\text { NCST Advisory Committee meeting on disposition of public } \\
\text { comments and update to draft reports for the WTC towers. }\end{array}$ \\
\hline $\begin{array}{l}\text { September } 13-15 \\
2005\end{array}$ & Gaithersburg, MD & $\begin{array}{l}\text { WTC Technical Conference for stakeholders and technical } \\
\text { community for dissemination of findings and recommendations } \\
\text { and opportunity for public to make technical comments. }\end{array}$ \\
\hline
\end{tabular}

- A dissemination and technical assistance program (DTAP) to (a) engage leaders of the construction and building community in ensuring timely adoption and widespread use of proposed changes to practices, standards, and codes resulting from the WTC Investigation and the R\&D program, and (b) provide practical guidance and tools to better prepare facility owners, contractors, architects, engineers, emergency responders, and regulatory authorities to respond to future disasters.

The desired outcomes are to make buildings, occupants, and first responders safer in future disaster events. 


\section{National Construction Safety Team Reports on the WTC Investigation}

A final report on the collapse of the WTC towers is being issued as NIST NCSTAR 1. A companion report on the collapse of WTC 7 is being issued as NIST NCSTAR 1A. The present report is one of a set that provides more detailed documentation of the Investigation findings and the means by which these technical results were achieved. As such, it is part of the archival record of this Investigation. The titles of the full set of Investigation publications are:

NIST (National Institute of Standards and Technology). 2005. Federal Building and Fire Safety Investigation of the World Trade Center Disaster: Final Report on the Collapse of the World Trade Center Towers. NIST NCSTAR 1. Gaithersburg, MD, September.

NIST (National Institute of Standards and Technology). 2006. Federal Building and Fire Safety Investigation of the World Trade Center Disaster: Final Report on the Collapse of World Trade Center 7. NIST NCSTAR 1A. Gaithersburg, MD.

Lew, H. S., R. W. Bukowski, and N. J. Carino. 2005. Federal Building and Fire Safety Investigation of the World Trade Center Disaster: Design, Construction, and Maintenance of Structural and Life Safety Systems. NIST NCSTAR 1-1. National Institute of Standards and Technology. Gaithersburg, MD, September.

Fanella, D. A., A. T. Derecho, and S. K. Ghosh. 2005. Federal Building and Fire Safety Investigation of the World Trade Center Disaster: Design and Construction of Structural Systems. NIST NCSTAR 1-1A. National Institute of Standards and Technology. Gaithersburg, MD, September.

Ghosh, S. K., and X. Liang. 2005. Federal Building and Fire Safety Investigation of the World Trade Center Disaster: Comparison of Building Code Structural Requirements. NIST

NCSTAR 1-1B. National lnstitute of Standards and Technology. Gaithersburg, MD, September.

Fanella, D. A., A. T. Derecho, and S. K. Ghosh. 2005. Federal Building and Fire Safety Investigation of the World Trade Center Disaster: Maintenance and Modifications to Structural Systems. NIST NCSTAR 1-1C. National Institute of Standards and Technology. Gaithersburg, MD, September.

Grill, R. A., and D. A. Johnson. 2005. Federal Building and Fire Safety Investigation of the World Trade Center Disaster: Fire Protection and Life Safety Provisions Applied to the Design and Construction of World Trade Center 1, 2, and 7 and Post-Construction Provisions Applied after Occupancy. NIST NCSTAR 1-1D. National Institute of Standards and Technology. Gaithersburg, MD, September.

Razza, J. C., and R. A. Grill. 2005. Federal Building and Fire Safety Investigation of the World Trade Center Disaster: Comparison of Codes, Standards, and Practices in Use at the Time of the Design and Construction of World Trade Center 1, 2, and 7. NIST NCSTAR 1-1E. National Institute of Standards and Technology. Gaithersburg, MD, September.

Grill, R. A., D. A. Johnson, and D. A. Fanella. 2005. Federal Building and Fire Safety Investigation of the World Trade Center Disaster: Comparison of the 1968 and Current (2003) New 
York City Brilding Code Provisions. NIST NCSTAR 1-1F. National Institutc of Standards and Technology. Gaithersburg, MD, Scptcmber.

Grill, R. A., and D. A. Johnson. 2005. Federal Building and Fire Safety Investigation of the World Trade Center Disaster: Amendments to the Fire Protection and Life Safety Provisions of the New York City Building Code by Local Laws Adopted While World Trade Center 1, 2, and 7 Were in Use. NIST NCSTAR 1-1G. National Institute of Standards and Technology. Gaithersburg, MD, September.

Grill, R. A., and D. A. Johnson. 2005. Federal Building and Fire Safety Investigation of the World Trade Center Disaster: Post-Construction Modifications to Fire Protection and Life Safety Systems of World Trade Center 1 and 2. NIST NCSTAR 1-1H. National Institute of Standards and Technology. Gaithersburg, MD, Septembcr.

Grill, R. A., D. A. Johnson, and D. A. Fanella. 2005. Federal Building and Fire Safety Investigation of the World Trade Center Disaster: Post-Construction Modifications to Fire Protection, Life Safety, and Structural Systems of World Trade Center 7. NIST NCSTAR 1-11. National Institute of Standards and Technology. Gaithersburg, MD, September.

Grill, R. A., and D. A. Johnson. 2005. Federal Building and Fire Safety Investigation of the World Trade Center Disaster: Design, Installation, and Operation of Fuel System for Emergency Power in World Trade Center 7. NIST NCSTAR 1-1J. National Institute of Standards and Technology. Gaithersburg, MD, September.

Sadek, F. 2005. Federal Building and Fire Safety Investigation of the World Trade Center Disaster: Baseline Structural Performance and Aircraft Impact Damage Analysis of the World Trade Center Towers. NIST NCSTAR 1-2. National Institute of Standards and Technology. Gaithersburg, MD, September.

Faschan, W. J., and R. B. Garlock. 2005. Federal Building and Fire Safety Investigation of the World Trade Center Disaster: Reference Structural Models and Baseline Performance Analysis of the World Trade Center Towers. NIST NCSTAR 1-2A. National Institute of Standards and Technology. Gaithersburg, MD, September.

Kirkpatrick, S. W., R. T. Bocchieri, F. Sadek, R. A. MacNeill, S. Holmes, B. D. Peterson, R. W. Cilke, C. Navarro. 2005. Federal Building and Fire Safety Investigation of the World Trade Center Disaster: Analysis of Aircraft Impacts into the World Trade Center Towers, NIST NCSTAR 1-2B. National Institute of Standards and Technology. Gaithersburg, MD, September.

Gayle, F. W., R. J. Fields, W. E. Luecke, S. W. Banovic, T. Foecke, C. N. McCowan, T. A. Siewert, and J. D. McColskey. 2005. Federal Building and Fire Safety Investigation of the World Trade Center Disaster: Mechanical and Metallmrgical Analysis of Structural Steel. NIST NCSTAR 1-3. National Institute of Standards and Technology. Gaithersburg, MD, September.

Luecke, W. E., T. A. Siewert, and F. W. Gayle. 2005. Federal Building and Fire Safety Investigation of the World Trade Center Disaster: Contemporaneous Structural Steel Specifications. NIST Special Publication 1-3A. National Institute of Standards and Technology. Gaithersburg, MD, September. 
Banovic, S. W. 2005. Federal Building and Fire Safety Investigation of the World Trade Center Disaster: Steel Inventory and Identification. NIST NCSTAR 1-3B. National Institute of Standards and Technology. Gaithersburg, MD, September.

Banovic, S. W., and T. Foecke. 2005. Federal Building and Fire Safety Investigation of the World Trade Center Disaster: Dannage and Failure Modes of Structural Steel Components. NIST NCSTAR 1-3C. National Institute of Standards and Technology. Gaithersburg, MD, September.

Luecke, W. E., J. D. McColskey, C. N. McCowan, S. W. Banovic, R. J. Fields, T. Foecke, T. A. Siewert, and F. W. Gayle. 2005. Federal Building and Fire Safety Investigation of the World Trade Center Disaster: Mechanical Properties of Structural Steels. NIST NCSTAR 1-3D. National Institute of Standards and Technology. Gaithersburg, MD, September.

Banovic, S. W., C. N. McCowan, and W. E. Luecke. 2005. Federal Building and Fire Safety Investigation of the World Trade Center Disaster: Physical Properties of Structural Steels. NIST NCSTAR 1-3E. National Institute of Standards and Technology. Gaithersburg, MD, September.

Evans, D. D., R. D. Peacock, E. D. Kuligowski, W. S. Dols, and W. L. Grosshandler. 2005. Federal Building and Fire Safety Investigation of the World Trade Center Disaster: Active Fire Protection Systelns. NIST NCSTAR 1-4. National Institute of Standards and Technology. Gaithersburg, MD, September.

Kuligowski, E. D., D. D. Evans, and R. D. Peacock. 2005. Federal Building and Fire Safety Investigation of the World Trade Center Disaster: Post-Construction Fires Prior to September II, 2001. NIST NCSTAR 1-4A. National Institute of Standards and Technology. Gaithersburg, MD, September.

Hopkins, M., J. Schoenrock, and E. Budnick. 2005. Federal Building and Fire Safety Investigation of the World Trade Center Disaster: Fire Suppression Systems. NIST NCSTAR 1-4B. National Institute of Standards and Technology. Gaithersburg, MD, September.

Keough, R. J., and R. A. Grill. 2005. Federal Building and Fire Safety Investigation of the World Trade Center Disaster: Fire Alarm Systems. NIST NCSTAR 1-4C. National Institute of Standards and Technology. Gaithersburg, MD, September.

Ferreira, M. J., and S. M. Strege. 2005. Federal Building and Fire Safety Investigation of the World Trade Center Disaster: Smoke Management Systems. NIST NCSTAR 1-4D. National Institute of Standards and Technology. Gaithersburg, MD, September.

Gann, R. G., A. Hamins, K. B. McGrattan, G. W. Mulholland, H. E. Nelson, T. J. Ohlemiller, W. M. Pitts, and K. R. Prasad. 2005. Federal Building and Fire Safety Investigation of the World Trade Center Disaster: Reconstruction of the Fires in the World Trade Center Towers. NIST NCSTAR 1-5. National Institute of Standards and Technology. Gaithersburg, MD, September.

Pitts, W. M., K. M. Butler, and V. Junker. 2005. Federal Building and Fire Safety Investigation of the World Trade Center Disaster: Visual Evidence, Dannage Estimates, and Timeline Analysis. NIST NCSTAR 1-5A. National Institute of Standards and Technology. Gaithersburg, MD, September. 
Hamins, A., A. Maranghides, K. B. McGrattan, E. Johnsson, T. J. Ohlemiller, M. Donnelly, J. Yang, G. Mulholland, K. R. Prasad, S. Kukuek, R. Anleitner and T. MeAllister. 2005. Federal Building and Fire Safety Investigation of the World Trade Center Disaster: Experiments and Modeling of Structural Steel Elements Exposed to Fire. NIST NCSTAR 1-5B. National Institute of Standards and Teehnology. Gaithersburg, MD, September.

Ohlemiller, T. J., G. W. Mulholland, A. Maranghides, J. J. Filliben, and R. G. Gann. 2005. Federal Building and Fire Safety Investigation of the World Trade Center Disaster: Fire Tests of Single Office Workstations. NIST NCSTAR 1-5C. National Institute of Standards and Teehnology. Gaithersburg, MD, September.

Gann, R. G., M. A. Riley, J. M. Repp, A. S. Whittaker, A. M. Reinhorn, and P. A. Hough. 2005. Federal Building and Fire Safety Investigation of the World Trade Center Disaster: Reaction of Ceiling Tile Systems to Shocks. NIST NCSTAR 1-5D. National Institute of Standards and Technology. Gaithersburg, MD, September.

Hamins, A., A. Maranghides, K. B. MeGrattan, T. J. Ohlemiller, and R. Anleitner. 2005. Federal Building and Fire Safety Investigation of the World Trade Center Disaster: Experiments and Modeling of Multiple Workstations Burning in a Compartment. NIST NCSTAR I-5E. National Institute of Standards and Technology. Gaithersburg, MD, September.

MeGrattan, K. B., C. Bouldin, and G. Forney. 2005. Federal Building and Fire Safety Investigation of the World Trade Center Disaster: Computer Simulation of the Fires in the World Trade Center Towers. NIST NCSTAR 1-5F. National Institute of Standards and Technology. Gaithersburg, MD, September.

Prasad, K. R., and H. R. Baum. 2005. Federal Building and Fire Safety Investigation of the World Trade Center Disaster: Fire Structure Interface and Thermal Response of the World Trade Center Towers. NIST NCSTAR 1-5G. National Institute of Standards and Teehnology. Gaithersburg, $\mathrm{MD}$, September.

Gross, J. L., and T. MeAllister. 2005. Federal Building and Fire Safety Investigation of the World Trade Center Disaster: Structural Fire Response and Probable Collapse Sequence of the World Trade Center Towers. NIST NCSTAR I-6. National Institute of Standards and Teehnology. Gaithersburg, MD, September.

Carino, N. J., M. A. Starnes, J. L. Gross, J. C. Yang, S. Kukuek, K. R. Prasad, and R. W. Bukowski. 2005. Federal Building and Fite Safety Investigation of the World Trade Center Disaster: Passive Fire Protection. NIST NCSTAR 1-6A. National Institute of Standards and Teehnology. Gaithersburg, MD, September.

Gross, J., F. Hervey, M. Izydorek, J. Mammoser, and J. Treadway. 2005. Federal Building and Fire Safety Investigation of the World Trade Center Disaster: Fire Resistance Tests of Floor Truss Systems. NIST NCSTAR 1-6B. National Institute of Standards and Teehnology. Gaithersburg, $\mathrm{MD}$, September.

Zarghamee, M. S., S. Bolourehi, D. W. Eggers, Ö. O. Erbay, F. W. Kan, Y. Kitane, A. A. Liepins, M. Mudloek, W. I. Naguib, R. P. Ojdrovie, A. T. Sarawit, P. R Barrett, J. L. Gross, and 
T. P. McAllister. 2005. Federal Building and Fire Safety Investigation of the World Trade Center Disaster: Component, Connection, and Subsystem Structural Analysis. NIST NCSTAR 1-6C. National Institute of Standards and Technology. Gaithersburg, MD, September.

Zarghamee, M. S., Y. Kitane, Ö. O. Erbay, T. P. McAllister, and J. L. Gross. 2005. Federal Building and Fire Safety Investigation of the World Trade Center Disaster: Global Structural Analysis of the Response of the World Trade Center Towers to Impact Danage and Fire. NIST NCSTAR 1-6D. National Institute of Standards and Technology. Gaithersburg, MD, September.

McAllister, T., R. W. Bukowski, R. G. Gann, J. L. Gross, K. B. McGrattan, H. E. Nelson, L. Phan, W. M. Pitts, K. R. Prasad, F. Sadek. 2006. Federal Building and Fire Safety Investigation of the World Trade Center Disaster: Structural Fire Response and Probable Collapse Sequence of World Trade Center 7. (Provisional). NIST NCSTAR 1-6E. National Institute of Standards and Technology. Gaithersburg, MD.

Gilsanz, R., V. Arbitrio, C. Anders, D. Chlebus, K. Ezzeldin, W. Guo, P. Moloney, A. Montalva, J. Oh, K. Rubenacker. 2006. Federal Building and Fire Safety Investigation of the World Trade Center Disaster: Structural Analysis of the Response of World Trade Center 7 to Debris Damage and Fire. (Provisional). NIST NCSTAR 1-6F. National Institute of Standards and Technology. Gaithersburg, MD.

Kim, W. 2006. Federal Building and Fire Safety Investigation of the World Trade Center Disaster: Analysis of Septenber 11, 2001, Seismogram Data. (Provisional). NIST NCSTAR 1-6G. National Institute of Standards and Technology. Gaithersburg, MD.

Nelson, K. 2006. Federal Building and Fire Safety Investigation of the World Trade Center Disaster: The Con Ed Substation in World Trade Center 7. (Provisional). NIST NCSTAR 1-6H. National Institute of Standards and Technology. Gaithersburg, MD.

Averill, J. D., D. S. Mileti, R. D. Peacock, E. D. Kuligowski, N. Groner, G. Proulx, P. A. Reneke, and H. E. Nelson. 2005. Federal Building and Fire Safety Investigation of the World Trade Center Disaster: Occupant Behavior, Egress, and Emergency Communication. NIST NCSTAR 1-7. National Institute of Standards and Technology. Gaithersburg, MD, September.

Fahy, R., and G. Proulx. 2005. Federal Building and Fire Safety Investigation of the World Trade Center Disaster: Analysis of Published Accounts of the World Trade Center Evacuation. NIST NCSTAR 1-7A. National Institute of Standards and Technology. Gaithersburg, MD, September.

Zmud, J. 2005. Federal Building and Fire Safety Investigation of the World Trade Center Disaster: Technical Documentation for Survey Administration. NIST NCSTAR 1-7B. National Institute of Standards and Technology. Gaithersburg, MD, September.

Lawson, J. R., and R. L. Vettori. 2005. Federal Building and Fire Safety Investigation of the World Trade Center Disaster: The Emergency Response Operations. NIST NCSTAR 1-8. National Institute of Standards and Technology. Gaithersburg, MD, September. 


\section{EXECUTIVE SUMMARY}

As part of the analysis of building and fire codes and practices of the National Institute of Standards and Technology (NIST) World Trade Center (WTC) lnvestigation, this report supports the cffort to document the changes in building code regulations that occurred after construction of WTC 1 and WTC 2.

WTC 1 and WTC 2 were to be designed and constructed in accordance with the Building Code of the City of New York (BCNYC) as enacted by Local Law No. 76 for the year 1968, effective December 6, 1968 (refcrred to as the "new code").

This report is not intended to give a complete history of the BCNYC. The purpose of this report is to provide an evolution of the life safcty provisions of the BCNYC since the design of WTC 1 and WTC 2, including retroactive provisions for existing high-rise office towers. The evolution of the New York City code begins with a brief overview of the BCNYC prior to 1968 (referred to as the "old code") and reviews the various local laws that have amended fire protection and life safety provisions of the code from 1968 until the collapse of the WTC towers on Scptember 11, 2001.

The BCNYC that becamc effective on January 1, 1938, had remaincd in effect and was edited and amended by local laws until 1968. Local Law 76 for the year 1968 repcaled the 1938 BCNYC; however, buildings in existence prior to 1968 are still permitted to be altered in accordance with the $1938 \mathrm{BCNYC}$, provided the general safety and public welfare are not thereby endangered, in the opinion of the Authority Having Jurisdiction.

The BCNYC is a part of the Administrative Code of the City of New York. From 1968 until 1985, the BCNYC was part of Title ' $C$ ' of Chapter 26 of the Administrative Code. 1n 1985, the Administrative Code was reorganized and renumbered. The General Provisions of the Department of Buildings are currently organized under Chapter 1 of Title 26 - Housing and Buildings. The BCNYC is currently Chapter 1 of Title 27 - Construction and Maintenance. Due to the reorganization of the Administrative Code, BCNYC section numbers before 1985 are preceded with "C26-" and section numbers after 1985 are preceded by "27-."

To amend the Administrative Code of the City of New York, including the BCNYC, a bill (proposed legislation) must be introduced in the City Council. When the bill is approved by the City Council and signed by the Mayor, then it becomes a Local Law.

Through the years, serious incidents such as fires, and in most cases, fires that have resulted in the loss of innocent lives, have caused the need to change certain code requirements. In most cases, a Local Law added or modified requirements for new construction or major alterations. In other cases, the Local Law included retroactive provisions that were applicable to buildings existing on the effective date of such Local Law. 
The applicable Local Laws that have amended the fire protection and life safety provisions of the $\mathrm{BCNYC}$ include, but are not limited to:

1. 1970 - Local Law No. 54, Local Laws of the City of New York for the Year 1970 (effective date immediately), November 17, 1970

2. 1973 - Local Law No. 5, Fire Safety Requirements and Controls (effective date immediately except as noted), January 18, 1973

3. 1975 - Local Law No. 26, Local Laws of the City of New York for the Year 1975 (effective date immediately), June 2, 1975

4. 1976 - Local Law No. 55, Local Laws of the City of New York for the Year 1976 (effective date immediately), November 1, 1976

5. 1978 - Local Law No. 33, Local Laws of the City of New York for the Year 1978 (effective date immediately), October 6, 1978

6. 1978 - Local Law No. 41, Local Laws of the City of New York for the Year 1978 (effective 30 days after enactment), December 13, 1978

7. 1979 - Local Law No. 84, Fire Safety Pressurization Requirements in Certain Office Buildings (effective date immediately), December 13, 1979

8. 1979 - Local Law No. 86, Dates for Compliance with the Local Laws Enacted for Fire Safety Requirements and Controls in Certain Buildings (effective date immediately), December 13, 1979

9. 1984 - Local Law No. 16, Local Laws of thc City of New York for the Year 1984 (effective date immediately except as noted), March 27, 1984

10. 1987 - Local Law No. 16, Local Laws of the City of New York for the Year 1987 (effective date immediately), April 20, 1987

Since 1968, the BCNYC Reference Standards have been updated by various New York City procedures and authorities including Local Laws passed by the City Council, Building Code Rules approved by the New York City Board of Standards and Appeals until 1991, and by the authority of the Building Commissioner, after 1991. Included in this report is a summary of the applicable fire protection and life safety reference standards and the effective dates. Most Reference Standards are nationally recognized standards (ASTM International, National Fire Protection Association, etc.) that New York City references (often with New York City modifications). Other Reference Standards are developed by the New York City Department of Buildings (e.g., Standpipe Construction, Fire Alarm Systems). 


\section{Chapter 1 \\ INTRODUCTION}

The purpose of this report is to provide an evolution of the lifc safety provisions of the Building Code of the City of New York (BCNYC) since the design of World Trade Center (WTC) 1 and WTC 2, including retroactive provisions for existing high-rise officc towers.

WTC 1 and WTC 2 were to be designed and constructed in accordance with the BCNYC as enacted by Local Law No. 76 for the year 1968, effective Dccomber 6, 1968 (rcferred to as the "new code").

The BCNYC is a part of the Administrative Code of the City of New York. The latest major overhaul of the BCNYC occurred in 1968. Since then, several Local Laws have been approved by the City Council and the Mayor of the City of New York to amend the BCNYC. Most Local Laws amend certain provisions of the BCNYC and pertain to new construction or new installations of equipment. However, some Local Laws have retroactive provisions that apply to existing buildings or structures.

The first Local Law that is signed by the Mayor for a particular year is Local Law No. 1 for that year. It is important to associate a Local Law number with the year it was passed. For example, Local Law No. 5 for the year 1973 is not the same as Local Law No. 5 for 1972 or Local Law No. 5 for 1974, ctc.

This report is intended to summarize the Local Laws that have had an impact on fire protection and life safety related requirements and that may provide an understanding about the requirements that were applicable in the design, construction, and alterations of WTC 1,2, and 7.

The most notable of the Local Laws that have amended the fire protection and life safety provisions of the BCNYC are Local Law No. 5 for the year 1973 and Local Law No. 16 for the year 1984. Local Law No. 5 and Local Law No. 16 contain several retroactive fire protection and life-safety-related requirements for existing buildings, including automatic sprinkler systems, compartmentation, stair pressurization, fire alarm and communication systems, emergency power systems and smoke control provisions.

Chapter 2 includes a list of the Local Laws containing fire protection and life safety provisions.

Table 2-1 provides the effective dates of various Local Laws amending the BCNYC. The Local Laws containing fire protection and life safety provisions are presented in Chapter 4 in chronological order beginning with Local Law No. 54 for the year 1970.

In addition to the BCNYC, several amendments have been made to the Reference Standards of the Code. As the Code was updated and new technologies and industry standards became available, it was necessary to update the Reference Standards. Most Reference Standards are nationally recognized standards such as those published by the American National Standards Institute, ASTM International and the National Fire Protection Association. Other Reference Standards are promulgated by the New York City Department of Buildings, such as the reference standards for standpipe systems and the Reference Standards for fire alarm systems. 
This page intentionally left blank. 


\section{Chapter 2 \\ GENERAL}

\subsection{LOCAL LAWS CONTAINING FIRE PROTECTION/LIFE SAFETY PROVISIONS}

1. 1970 - Local Law No. 54, Local Laws of the City of New York for the Year 1970 (effective date immediately), November 17, 1970

2. 1973 - Local Law No. 5, Fire Safety Requirements and Controls (effective date immediately except as noted), January 18,1973

3. 1975 - Local Law No. 26, Local Laws of the City of Ncw York for the Year 1975 (effective date immediately), June 2, 1975

4. 1976 - Local Law No. 55, Local Laws of the City of New York for the Year 1976 (effective date immediately), November 1, 1976

5. 1978 - Local Law No. 33, Local Laws of the City of New York for the Year 1978 (effective date immediately), October 6, 1978

6. 1978 - Local Law No. 41, Local Laws of the City of New York for the Year 1978 (effective 30 days after enactment), December 13, 1978

7. 1979 - Local Law No. 84, Fire Safety Pressurization Requirements in Certain Office Buildings (effective date immediately), December 13, 1979

8. 1979 - Local Law No. 86, Dates for Compliance with the Local Laws Enacted for Fire Safety Requirements and Controls in Certain Buildings (effective date immediately), December 13, 1979

9. 1984 - Local Law No. 16, Local Laws of the City of New York for the Year 1984 (effective date immediately except as noted), March 27, 1984

10. 1987 - Local Law No. 16, Local Laws of the City of New York for the Year 1987 (effective date immediately), April 20, 1987 
EFFECTIVE DATES OF LOCAL LAWS AMENDING THE BUILDING CODE

Table 2-1. Effective dates of Local Laws.

\begin{tabular}{|c|c|c|c|}
\hline Year & Local Law & Effective Date & Comments \\
\hline 1969 & 61 & December 4, 1969 & \\
\hline 1969 & 65 & December 22, 1969 & \\
\hline 1969 & 73 & December 20, 1969 & \\
\hline 1970 & 54 & November 17,1970 & $\begin{array}{l}\text { Fire protection/life safety } \\
\text { amendments }\end{array}$ \\
\hline 1971 & 75 & December 22, 1971 & \\
\hline 1972 & 39 & June 1,1972 & \\
\hline 1972 & 76 & November 6, 1972 & \\
\hline 1973 & 5 & January 18,1973 & $\begin{array}{l}\text { Fire protection/life safety } \\
\text { amendments with retroactive } \\
\text { requirements for office buildings }\end{array}$ \\
\hline 1973 & 50 & September 21, 1973 & \\
\hline 1973 & 58 & October 15,1973 & \\
\hline 1973 & 80 & December 28,1973 & \\
\hline 1973 & 85 & December 28,1973 & \\
\hline 1974 & 7 & May 16,1974 & \\
\hline 1975 & 13 & March 31,1975 & \\
\hline 1975 & 26 & June 2,1975 & \\
\hline 1976 & 55 & November 1, 1976 & \\
\hline 1976 & 63 & December 10,1976 & \\
\hline 1977 & 67 & September 30, 1977 & \\
\hline 1977 & 69 & September 30,1977 & \\
\hline 1978 & 41 & January 1979 & \\
\hline 1979 & 79 & December 4, 1979 & \\
\hline 1979 & 84 & December 14,1979 & \\
\hline 1979 & 86 & December 14,1979 & \\
\hline 1981 & 21 & March 19, 1981 & \\
\hline 1982 & 12 & March 5, 1982 & \\
\hline 1982 & 30 & June 15,1982 & \\
\hline 1983 & 58 & November 16,1983 & \\
\hline 1984 & 16 & March 27, 1984 & $\begin{array}{l}\text { Fire protection/life safety } \\
\text { amendments with retroactive } \\
\text { requirements }\end{array}$ \\
\hline 1984 & 45 & July 12,1984 & \\
\hline 1986 & 80 & December 22, 1986 & \\
\hline 1986 & 82 & December 30,1986 & \\
\hline 1987 & 9 & March 5, 1987 & \\
\hline 1987 & 13 & March 23, 1987 & \\
\hline
\end{tabular}




\begin{tabular}{|c|c|c|c|}
\hline Year & Local Law & Effective Date & Comments \\
\hline 1987 & 16 & April 20, 1987 & Amended Local Law 16/1984 \\
\hline 1987 & 29 & June 30,1987 & \\
\hline 1987 & 40 & July 6,1987 & \\
\hline 1987 & 58 & August 5, 1987 & \\
\hline 1987 & 61 & November 3,1987 & \\
\hline 1988 & 11 & March 9, 1988 & \\
\hline 1988 & 33 & May 27,1988 & \\
\hline 1988 & 34 & February 2,1988 & \\
\hline 1988 & 46 & July 11,1988 & \\
\hline 1988 & 49 & July 11,1988 & \\
\hline 1988 & 50 & July 11,1988 & \\
\hline 1988 & 58 & January 1,1989 & \\
\hline 1988 & 65 & November 4,1988 & \\
\hline 1988 & 73 & December 8, 1988 & \\
\hline 1988 & 77 & June 8,1988 & \\
\hline 1989 & 14 & April 13, 1989 & \\
\hline 1989 & 29 & November 16, 1989 & \\
\hline 1989 & 38 & June 28,1989 & \\
\hline 1989 & 55 & January 25,1990 & \\
\hline 1989 & 80 & November 8,1989 & \\
\hline 1989 & 81 & February 6,1990 & \\
\hline 1989 & 90 & December 6,1989 & \\
\hline 1989 & 100 & December 27, 1989 & \\
\hline 1989 & 103 & December 27,1989 & \\
\hline 1990 & 23 & July 7,1990 & \\
\hline 1990 & 38 & August 11, 1990 & \\
\hline 1990 & 65 & November 14,1990 & \\
\hline 1991 & 33 & August 23, 1991 & \\
\hline 1991 & 48 & July 1,1991 & \\
\hline 1991 & 49 & July 1,1991 & \\
\hline 1991 & 54 & July 1,1991 & \\
\hline 1991 & 55 & July 17,1991 & \\
\hline 1991 & 62 & January 1,1992 & \\
\hline 1991 & 72 & October 21,1991 & \\
\hline 1991 & 99 & February 21, 1992 & \\
\hline 1992 & 18 & March 9, 1992 & \\
\hline 1993 & 6 & March 22, 1993 & \\
\hline 1993 & 12 & January 22,1994 & \\
\hline 1993 & 13 & January 22,1994 & \\
\hline
\end{tabular}




\begin{tabular}{|c|c|c|l|}
\hline Year & Local Law & Effective Date & \multicolumn{1}{|c|}{ Comments } \\
\hline 1993 & 14 & February 9, 1993 & \\
\hline 1993 & 15 & February 9, 1993 & \\
\hline 1993 & 39 & May 28, 1993 & \\
\hline 1993 & 53 & June 30, 1993 & \\
\hline 1993 & 56 & June 30, 1993 & \\
\hline 1999 & 10 & March 24, 1999 & $\begin{array}{l}\text { Residential sprinklers and fire } \\
\text { safety plans }\end{array}$ \\
\hline 2002 & 26 & August 15, 2002 & Mercantile sprinklers \\
\hline
\end{tabular}

Source: Building Code of the City of New York. 


\section{Chapter 3 \\ HISTORY OF THE NEW YORK CITY BUILDING CODE}

Building regulations in New York City date back to 1625 when the Dutch West India Company established rules for the types and locations of houses that could be built by the colonists of New Amsterdam. Extensive laws governing construction and fire prevention were in place by 1674 .

This chapter is not intended to give a complete history of the Building Code of the City of New York (BCNYC). The specific task of this report is to provide an understanding of the evolution of the BCNYC since the design of World Trade Center (WTC) 1 and WTC 2, which is understood to be circa 1968. Since the current BCNYC permits buildings in existence prior to December 6, 1968, to be altered in compliance with the applicable laws in existence prior to 1968, this chapter also includes a brief overview of the 1938 Building Code, often referred to as the "old code."

\section{$3.1 \quad 1938$ BUILDING CODE (OLD CODE)}

The BCNYC in existence prior to 1938 was repealed and replaced with a code that became effective on January 1, 1938. For 30 years, this version of the BCNYC was enforced throughout the five boroughs of New York City. It was edited and amended by Local Laws on December 6, 1968, when Local Law No. 76 for the year 1968 repealed the 1938 Code. Buildings in existence prior to 1968 are permitted to be altered in accordance with the $1938 \mathrm{BCNYC}$, provided the general safety and public welfare are not thereby endangered in the opinion of the Authorities Having Jurisdiction.

\subsection{BUILDING CODE (THEN CURRENT CODE)}

On November 6, 1968, Local Law No. 76 of the City of New York was approved by the Mayor. Local Law No. 76 was "A Local Law to amend the New York City charter and the administrative code of the city of New York, in relation to revising the city's code and providing for powers and duties of the department of buildings and certain other city departments with respect to buildings and matters related thereto."

Titles A, B, and C of Chapter 26 of the Administrative Code of the City of New York (the 1938 BCNYC) were repealed and reenacted under sec. 1 of Local Law No. 76. Part II of Title C is known and may be cited as the "building code of the city of New York" (Sec. C26-100.1).

The Local Law became effective 30 days after it was enacted. Therefore, the effective date of Local Law No. 76 for the year 1968, including the Building Code, is December 6, 1968.

Among other requirements, occupancy and construction classifications changed from the $1938 \mathrm{BCNYC}$ to the 1968 BCNYC. For example, an office building constructed in accordance with the 1938 BCNYC is classified as a commercial occupancy, whereas the same building in the 1968 BCNYC is classified as Occupancy Group E-Business. Under the 1938 BCNYC, a tall office building must be constructed in the construction classification of fireproof $(4 \mathrm{~h})$. The same building constructed under the 
1968 BCNYC may be constructed in construction type IA (4 h) or IB (3 h). In 1973, Local Law No. 5 (1973) added another possible classification, IC ( $2 \mathrm{~h})$, which required the installation of automatic sprinklers. 


\section{Chapter 4 \\ EVOLUTION OF BUILDING CODE SINCE 1968}

Through the ycars, serious incidents such as fircs, and in most cases, fires that have resulted in the loss of innocent lives, have caused the necd to ehange ecrtain code requirements. In most eases, a Local Law added rcquirements for new construction or major alterations. In other cases, the Local Law included retroactive provisions that wcre applicable to buildings cxisting on the effective date of such Local Law.

This chapter identifies the Local Laws that have included substantial modifications to the fire protection and/or life safety provisions of Building Code of the City of New York (BCNYC). Highlights of each of the Local Laws are provided.

\subsection{0 - LOCAL LAW NO. 54, POWERS AND DUTIES OF THE DEPARTMENT OF BUILDINGS}

Local Law No. 54 for the ycar 1970 (LL 54/1970) was approved "to amend the administrative code of the city of New York, in relation to further clarifying and corrccting provisions relating to the powers and duties of the department of buildings."

Although the title of LL 54/1970 refers to powcrs and duties of the department of buildings, LL 54/1970 amended several seetions of the Building Code, including the following fire protection/life safety provisions:

- C26-504.6 - Shafts (LL 54, sec. 4)

- C26-600.3 - Inadequate exits for existing structures (LL 54, see. 5)

- C26-604.3(h)(3) - Street floor lobbies as exit passageways (LL 54, sec. 6)

- C26-604.4(j)(1)(b) - Locking of doors opening into interior enclosed stairs (LL 54, sec. 7)

- C26-604.8(b) - Width of interior enclosed stairs (LL 54, sec. 8)

- C26-604.8(i)(2) - Access stairs (LL 54, sec. 9)

- Table 6-1 - Exit and Access Requirements (LL 54, sec. 10)

- C26-1800.8 - Elevator in readiness (LL 54, see. 16)

- C26-1804.1 - Elevator operators (LL 54, sec. 17)

The new and amended requirements in LL 54/1970 were applicable to new construction and alterations after the effeetive date, but were not retroactive for existing buildings.

LL 54/1970 was approved by the Mayor on November 17, 1970, and became effective immediately. 


\subsection{3 - LOCAL LAW NO. 5, FIRE SAFETY REQUIREMENTS IN CERTAIN OFFICE BUILDINGS}

After five fatalities that occurred in two high-rise buildings in New York City in 1970, a Mayor's Advisory Committee on Fire Safety in High-Rise Buildings was commissioned to "undcrtake an extraordinary effort to further improve the safety of our major working environment, the high-rise tower." The Report of Mayor's Advisory Committee on Fire Safety in High-Rise Buildings was released in November 1971.

As a result of the report, Local Law No. 5 for the year 1973 (LL 5/1973) was approved by Mayor John V. Lindsay on January 18, 1973, and was to take effect immediately. LL 5/1973 was described as a "Local Law to amend the administrative code of the city of New York, in relation to fire safety requirements and controls in certain office buildings."

LL 5/1973 consists of 44 sections and at that time it was "the most comprehensive set of fire safety improvements ever proposed in any jurisdiction."

Enacted in 1973 and further amended by Local Law No. 26/1975 (LL 26/1975), LL 5/1973 was the subject of a lengthy period of litigation and appeals. The Court of Appeals rendered a final decision on December 26, 1978, upholding Local Law No. 5 in its entirety.

Sections of the Fire Prevention Code and Building Code were amended by LL 5/1973. This local law provided requirements for new buildings in occupancy group $\mathrm{E}$ as well as retroactive provisions in existing office buildings.

The major highlights of LL 5/1973 are summarized in the following sections.

\subsubsection{Fire Safety in Office Buildings}

A new sec. C19-161.2 was added to the New York City Fire Prevention Code to provide for fire safety in office buildings. This new section requires new occupancy group $\mathrm{E}$ buildings and existing office buildings with an occupant load of more than 100 persons above or below the street level or more than 500 persons in the entire building to provide a fire safety plan for fire drill and evacuation procedures. As part of the Fire Safety Plan, Fire Safety Directors, Deputy Fire Safety Directors, Building Evacuation Supervisors, and Fire Brigades must be provided. In addition, stair and elevator signs must be posted and maintained in accordance with the requirements of the BCNYC (LL 5, sec. 1).

\subsubsection{Compartmentation}

Section C26-504.1(c) was added to require unsprinklered floor areas, more than $40 \mathrm{ft}$ above curb level, in new buildings in occupancy group $\mathrm{E}$ and existing office buildings $100 \mathrm{ft}$ or more in height "having airconditioning and/or mechanical ventilation systems that serve more than the floor on which the equipment is located," to be subdivided by $1 \mathrm{~h}$ fire separations into spaces or compartments not to exceed 7,500 $\mathrm{ft}^{2}$. Floor areas may be increased up to $15,000 \mathrm{ft}^{2}$ if protected by $2 \mathrm{~h}$ fire-resistive construction and smoke detectors. Regardless of the floor area, compartmentation is not required when complete sprinkler protection is provided (LL 5, sec. 6). 


\subsubsection{Smoke and Heat Venting}

Section C26-504-15 was added to require new buildings in occupancy group E, $100 \mathrm{ft}$ or morc in height, having air-conditioning and/or mechanical ventilation systcms that scrve morc than the floor on which the equipment is located, to be provided with at least one smokc shaft by mcans of which smokc and heat shall be mechanically vented to the outdoors as provided in Referencc Standard (RS) 5-17.

Existing office buildings, $100 \mathrm{ft}$ or more in height, having air-conditioning and/or mcchanical ventilation systems that serve more than the floor on which the equipment is located, have an option of providing the smoke shaft in accordance with RS 5-17 or in lieu of the smoke shafts, may providc a system of pressurization in all interior enclosed stairs other than a fire tower stair for emcrgency use only.

Buildings that are sprinklered throughout are exempt from the smoke shaft and stair pressurization requirements (LL 5, sec. 7).

\subsubsection{Means of Egress}

Several sections of Article 6 of the BCNYC were amended to provide for signs in new and existing office buildings regarding the use of elevators and stairs. Additional provisions permit all stair doors to be locked from the stair side in buildings less than $100 \mathrm{ft}$ in height. In buildings over $100 \mathrm{ft}$ in height, the stair doors on every fourth floor are required to be openable to provide for re-entry from the stair. However, all the doors may be locked if they are provided with safety features such as fail-safe system in the event of loss of power and interface with the fire alarm system and the phase I elevator recall system.

Section C26-600.1 was amended to clarify the scope of the reguiation with respect to new, altered, changed in occupancy, existing, and special use buildings (LL 5, sec. 8).

Section C26-604.4 was amended to permit locking of certain doors from the stair side in buildings in occupancy group E (LL 5, sec. 9).

Section C26-607.1 was amended to address retroactive provisions of LL 5/1973 for signs and exit lighting (LL 5, sec. 10).

Sub-Article 608 (secs. C26-608.1 through C26-608.7) was added regarding Stair and Elevator Signs in Office Buildings (LL 5, sec. 11).

\subsubsection{Sprinklers}

Subdivision (i) of sec. C26-1703.1 was added and Table 17-2 was amended to require sprinklers in showroom spaces exceeding $7,500 \mathrm{ft}^{2}$ in area and located more than $40 \mathrm{ft}$ above curb level in new buildings in occupancy group $\mathrm{E}$ and existing office buildings, $100 \mathrm{ft}$ or more in height having airconditioning and/or mechanical ventilation systems that serve more than the floor on which the equipment is located (LL 5, sec. 16).

Subdivision (d) was added to sec. C26-1702.14 and subdivision (g) was added to sec. C26-1703.9 to allow standpipe systems to be used to supply water to sprinklers in buildings classified in occupancy 
group E, $100 \mathrm{ft}$ or more in height, and in existing office buildings, $100 \mathrm{ft}$ or more in height, in accordance with the applicable provisions of RS 17-1 and RS 17-2 (LL 5, sec. 14, 20).

\subsubsection{Interior Fire Alarm Signal and Voice Communication Systems}

Prior to 1973, a fire alarm system was not required for a building in occupancy group E (new code) or commercial office buildings (old code). Only a standpipe fireline telephone and signaling system was required in buildings over $300 \mathrm{ft}$ in height for fire department use in operating the standpipe system.

A new paragraph (9) was added to sec. C26-1704.1(a) to require a fire alarm system in buildings classified in occupancy group E, $100 \mathrm{ft}$ or more in height (LL 5, sec. 21).

Two new subdivisions $(\mathrm{g})$ and $(\mathrm{h})$ were added to sec. C26-1704.4 to provide requirements for class $\mathrm{E}$ and modified class E fire alarm signal systems, respectively (LL 5, sec. 23).

Two new subdivisions ( $\mathrm{f}$ ) and (g) were added to sec. C26-1704.5 for the requirements of fire alarm systems in new buildings in occupancy group $\mathrm{E}$ and existing office buildings $100 \mathrm{ft}$ or more in height (LL 5, sec. 25).

Subdivision (h) was added to sec. C26-1704.5 for the requirements of two-way voice communication and fire alarm signal system for buildings in occupancy group E and existing office buildings, less than $100 \mathrm{ft}$ in height, occupied for an occupant load of more than 100 persons above or below the street level or more than a total of 500 pcrsons in the entire building (LL 5, sec. 25).

A new sec. C26-1704.8 was added regarding the requirements for communication systems and fire command station in buildings classified in occupancy group E $100 \mathrm{ft}$ or more in height, and existing office buildings $100 \mathrm{ft}$ or more in height (LL 5, sec. 30).

\subsubsection{Elevators}

Section C26-1800.8 was amended regarding an elevator in readiness in every building in occupancy group E, $100 \mathrm{ft}$ or more in height and in existing office buildings $100 \mathrm{ft}$ or more in height (LL 5, sec. 31).

\subsubsection{Reference Standards}

In addition to amending existing building code requirements or enacting new code requirements, LL 5/1973 also modified existing Reference Standards and added new Refcrence Standards as follows:

- $\quad$ RS 5-17, Standards for the Installation of Smoke Shafts (added LL 5, sec. 32).

- $\quad$ RS 5-18, Standards for the Pressurization of Stairs (added LL 5, sec. 33).

- $\quad$ RS 13-1, Standards for the Installation of Air Conditioning and Ventilating Systems, National Fire Protection Association (NFPA) No. 90-A, 1967, as modified, was amended to add a new sec. 1006 regarding manual controls and smoke detection requirements in buildings in occupancy group E, $100 \mathrm{ft}$ or more in height, where a system serves more than the floor on which the equipment is located (amended LL 5, sec. 34). 
- RS 16, Plumbing and Gas Piping (amended LL 5, scc. 35).

- $\quad$ RS 17-1, Standpipc Systcm Construction (amended LL 5, sec. 36, 37).

- $\quad$ RS 17-2, Standard for the Installation of Sprinkler Systcms, NFPA No. 13 - 1966, as modified (amended LL 5, scc. 38).

- RS 17-3A, Standards for the Installation of Class E Fire Alarn Signal Systems (new LL 5, sec. 39).

- RS 17-3B, Standards for the Installation of Modified Class E Fire Alarm Signal Systems (new LL 5, sec. 40).

- $\quad$ RS 18-1, USA Standard Safety Code for Elevators, Dumbwaiters, Escalators and Moving Walks, including Supplcment A17-1a -1967, as modified (amended LL 5, sec. 41, 42).

\subsection{5 - LOCAL LAW NO. 26, FIRE SAFETY IN OFFICE BUILDINGS}

LL 26/1975 was approved "to amend the administrative code of the city of New York, in relation to fire safety requirements and controls in certain office buildings."

LL 26/1975 revised the smoke and heat venting compliance dates previously established by LL 5/1973, as follows:

- C26-504.15(c) Smoke and heat venting - reviscd the completion date for compliance with the smoke and heat venting requirements to be within $4 \frac{1}{2}$ years after February 7, 1973. The completion date for existing buildings that were to be sprinklered throughout was established as February 7, 1979 (LL 26, scc. 1).

Note that the compliance dates revised by LL 26/1975 were further modified by Local Law No. 86 for the year 1979 (see Sec. 4.8 of this report).

LL 26/1975 was approved by the Mayor on June 2, 1975, and was effective immediately.

\section{$4.4 \quad 1976$ - LOCAL LAW NO. 55, INSPECTION OF SPRAYED-ON FIRE PROTECTION OF STRUCTURAL MEMBERS}

Local Law No. 55 for the year 1976 (LL 55/1976) was approved "to amend the administrative code of the city of New York, in relation to the fire protection of structural members."

A new subdivision (f) was added to sec. C26-502.2 mandating that the installation of all required sprayedon fire protection of structural members except those encased in concrete shall be subject to the controlled inspection requirements of C26-106.3 (LL 55, sec. 1).

LL 55/1976 was approved by the Mayor on November 1, 1976, and was effective immediately for new installations, but was not retroactive for installations that were filed with the Department of Buildings prior to November 1, 1976. 


\section{5 1978 - LOCAL LAW NO. 33, FIRE WARDENS IN OFFICE BUILDINGS}

Local Law No. 33 for the year 1978 (LL 33/1978) was approved "to amend the administrative code of the city of New York, in relation to tenant's employees as fire wardens in certain office buildings."

LL 33/1978 consists of two sections that amend a provision added to the Fire Prevention Code by LL 5/1973. The two sections pertain to fire safety plans and the designation and training of fire wardens and deputy fire wardens by the fire safety directors.

Section 1 adds a new paragraph 6 to sec. C19-161.2(a) requiring the tenant or tenants on each floor to provide responsible and dependable employees for designation and training by the fire safety director as fire wardens and deputy fire wardens to carry out their responsibilities as contained in the fire safety plan.

Section 2 amends C19-161.2(a)(2)(a) requiring the fire safety director to designate and train the fire wardens and deputy fire wardens provided by the tenants on each floor.

LL 33/1978 was signed by the Mayor on October 6, 1978, and was effective immediately. Since the LL 5/73 requirements for fire safety plans and fire safety directors were applicable to existing office buildings, the additional requirement for fire wardens and deputy fire wardens were also applicable to existing office buildings.

\subsection{8 - LOCAL LAW NO. 41, FIRE PROTECTION FOR PLACES OF ASSEMBLY}

After the tragic fire in the Blue Angel nightclub in midtown Manhattan in December 18, 1975, Local Law No. 41 for the year 1978 (LL 41/1978) was approved "to amend the administrative code of the city of New York, in relation to fire protection for places of assembly."

A place of assembly is defined in the BCNYC as "an enclosed room or space in which seventy-five or more persons gather for religious, recreational, educational, political or social purposes, or for the consumption of food or drink, or for similar group activities..." At the World Trade Center (WTC) complex, several cafeterias throughout the buildings and restaurants such as the Windows on the World on the 107th floor of WTC 1 are classified as occupancy group F-4 places of assembly.

Sections of the Fire Prevention Code and Building Code were amended by LL 41/1978 to require emergency lighting, sprinklers, and fire alarm signal systems in certain areas of places of assembly. LL 41/1978 included requirements for new places of assembly as well as retroactive provisions for existing places of assembly. The following code requirements are applicable for all new places of . assembly and include retroactive provisions for such existing places of assembly:

- C26-801.18, Emergency lighting - All new and existing assembly spaces are required to be provided with emergency lighting facilities sufficient to provide at least 5 foot candles of illumination at the floor level. Such lighting shall be on circuits that are separate from the general lighting and power circuits, either taken off ahead of the main switch or connected to a separate emergency power source, and be arranged to operate automatically in the event of failure of the normal lighting system. Compliance in existing buildings was to be completed within a one year time period (amended LL 41, sec. 11). 
- C26-802.0(b)(7)(g) - Automatic sprinklers for stagc arcas in ncw and cxisting occupancy group F-1a places of assembly within 1 ycar of the cffective datc (added LL 41, scc. 12).

- $\mathrm{C} 26-802.3(\mathrm{~b})(2)$ - Automatic sprinklers and firc alarm protection for stagcs, dressing rooms and property rooms in new and existing occupancy group F-1b places of asscmbly providing live entertainment within 1 year of effective date (addcd LL 41, sec. 13).

- C26-804.1(a)(3) and C26-804.1(b) - Automatic sprinklcrs and firc alarm protection in ncw and existing occupancy group F-4 places of asscmbly used as a cabaret ${ }^{1}$ within 1 ycar of effective date (added LL 41, secs. 14 and 15).

- C26-1703.1(j) - Automatic sprinkler systems in dressing rooms and property rooms used in conjunction with all new and existing places of assembly providing entertainment (amended LL 41, sec. 19).

- C26-1703.1(s) - Automatic sprinkler systcms in ncw and existing

- (1) occupancy group F-4 places of asscmbly used as cabarets.

- (2) stages within F-1a, F-1 b, F-3 or F-4 occupancies providing livc entertainment (added LL 41, sec. 20).

- C26-1704.1(a)(10) - Interior fire alarm and signal systems in new and existing

- (a) Stages, dressing rooms and property rooms used in conjunction with all places of assembly used as cabarets.

- (b) Places of assembly used as a cabaret (added LL 41, sec. 21).

LL 41/1978 was approved by the Mayor on December 13, 1978, and took effect 30 days after its enactment into law (January 12, 1979).

\subsection{9 - LOCAL LAW NO. 84, FIRE SAFETY PRESSURIZATION IN OFFICE BUILDINGS}

Local Law No. 84 for the year 1979 (LL 84/1979) was approved "to amend the administrative code of the city of New York, in relation to fire safety pressurization requirements in certain office buildings."

To accommodate the requirement for stair pressurization as added by LL 5/1973, the opening paragraph for shafts (C26-504.6) and the requirement for openings in stair enclosures (C26-604.8(j)) was editorially revised (LL 86, secs. 1 and 2).

1 Cabaret - The term cabaret shall mean any room, place, or space in which any musical entertainment, singing, dancing or other similar amusement is permitted in connection with an eating and drinking establishment. 
Section 3 of LL 84/1979 amends RS 5-18, Standards for the Installation of Pressurization of Stairs.

LL 84/1979 was approved by the Mayor on December 13, 1979, and became effective immediately.

\subsection{9 - LOCAL LAW NO. 86, REVISED COMPLIANCE DATES FOR LOCAL LAW NO. 5/1973}

Local Law No. 86 for the year 1979 (LL 86/1979) was approved "to amend the administrative code of the city of New York, in relation to the dates for compliance with the local law enacted for fire safety requirements and controls in certain office buildings."

Various provisions of Local Law No. 5 for the ycar 1973 (i.e., compartmentation, pressurization, interior fire alarm and communication, elevator in readiness) have been amcnded by LL 86/1979 to provide for new dates for compliance as follows:

- C26-504.1(c)(6) - Compartmentation - Existing office buildings $100 \mathrm{ft}$ or more in height shall comply as follows (amended LL 86, sec. 1):

- At least one-third of the total floor area of the building within 2 years of the effective date of LL 86/1979 (on or before December 13, 1981)

- At least two-thirds of the total floor area of the building on or before August 7, 1984

- Full compliance on or before February 7, 1988

- C26-504.15(c) - Smoke and heat venting - Existing office buildings $100 \mathrm{ft}$ or more in height that are requircd to provide smoke vents or stair pressurization shall complete installation within 2 years and 9 months of the effective date of this local law (by Scptember 13, 1982), or

- C26-504.15(c) - Sprinklers in lieu of smoke and heat venting - Existing buildings that are sprinklered throughout shall be exempt from the compartmentation and the smoke vent or stair pressurization requirements under the following conditions (amended LL 86, sec. 2):

- At least one-third of the total floor area of the building, including but not limited to the entrance lobby, corridors and elevator landing areas, is sprinklered within 2 years of the effective date of LL 86/1979 (on or before December 13, 1981),

- At least two-thirds of the total floor area of the building is sprinklered within 3 years (on or before December 13, 1982),

- The building is sprinklered throughout within 4 years (on or before December 13, 1983).

- C26-1704.5(f)(12) - Class E fire alarm signal system - Existing office buildings $100 \mathrm{ft}$ or more in height shall install a class $\mathrm{E}$ fire alarm signal system within 1 year and 9 months of the effective date of LL 86/1979 (on or before September 13, 1981), (amended LL 86, sec. 3), or 
- C26-1704.5(g)(10) - Modified Class E fire alarm system permitted in lieu of Class E fire alarm system - Existing office buildings $100 \mathrm{ft}$ or more in height shall comply within 1 year and 9 months of the effective date of LL 86/1979 (on or before September 13, 1981), (amended LL 86, see. 4),

- C26-1704.8(c) - Communication system and fire command station - Existing office buildings $100 \mathrm{ft}$ or more in height were required to install a one-way and two-way voice communication system and fire command station within 1 year and 9 months of the effective date of LL 86/1979 (on or before September 13, 1981), (amended LL 86, sec. 5),

- C26-1800.8(c) - Elevator in readiness - Existing office buildings $100 \mathrm{ft}$ or more in height were required to provide elevators for immediate use by the fire department within 1 year and 9 months of the effeetive date of LL 86/1979 (on or before September 13, 1981), (amended LL 86, see. 6).

LL 86/1979 was approved by the Mayor on December 13, 1979, and became effective immediately.

\section{$4.9 \quad 1984$ - LOCAL LAW NO. 16, FIRE SAFETY REQUIREMENTS IN CERTAIN BUILDINGS}

Local Law No. 16 for the year 1984 (LL 16/1984) was approved "To amend the administrative code of the city of New York, in relation to fire safety requirements in eertain buildings and repealing certain provisions thereof relating thereto." Not sinee Local Law No. 5/1973 was there as extensive a local law amending fire protection and life safety provisions of the BCNYC. LL 16/1984 consists of 40 pages with 100 sections of code amended.

Sections of the Fire Prevention Code and the Building Code were amended by LL 16/1984. This local law provided additional fire protection and life safety requircments for new buildings in most occupaney groups and retroactive provisions for existing buildings in most occupaney groups, but primarily buildings in oceupancy group J-1 (hotels).

The major highlights of LL 16/1984 are summarized in the following sections.

\subsubsection{Fire Safety Requirements}

Section C19-161.3 of the New York City Fire Prevention Code was added rcquiring all new and existing buildings, when required by the BCNYC, to be provided with sprinklers, exit lighting, exit signs. stair and elevator signs, signs in sleeping rooms, fire alarms, communication systems, and fire command stations (LL 16/1984, sec. 3). 


\subsubsection{Alterations to Existing Buildings}

Section C26-103.0 of the BCNYC was amended regarding alterations of existing buildings. Three new subdivisions were added requiring the following provisions to apply to alterations of existing buildings, regardless of magnitude or cost (LL 16/1984, sec. 8):

1. Interior finish work, as provided in sec. C26-504.10

2. Finish flooring and floor covering, as provided in C26-504.13

3. The installation or replacement of elevators, as provided in article 18

\subsubsection{Fire Protection Plan}

A new sub-article 124.0 (secs. C26-124.1 through C26-124.4) was added requiring a fire protection plan ${ }^{2}$ for certain new buildings, including all high-rise buildings. The requirement for fire protection plans was also applicable retroactively to the construction of buildings in progress and not yet completed on the effective date (March 27, 1984) and to alterations to an existing building or building section if the cost of the alteration exceeded one million dollars or involved a change of use. Section C26-124.2 outlines the scope of items to be included in the fire protection plan (LL 16/1984, sec. 12).

\subsubsection{Special Filing Requirements}

A new sub-article 125.0 (sec. C26-125.1) was added requiring the owners of all existing buildings, which are required to comply with certain provisions of LL 16/1984 to file a report with the New York City Department of Buildings on or before April 1, 1987, certifying the installation of the required fire protection systems (LL 16/1984, sec. 12). The provisions include:

- C26-504.16(a) - Elevator vestibules

- C26-605.1 and C26-605.2(b) - Exit lighting

- $\quad$ C26-606.2(b) - Exit signs

- C26-609.3 - Signs in sleeping rooms

- C26-1300.9 - Ventilation in existing J-1 buildings

- C26-1700.7(b) - Sprinklers, fire alarm systems, fire command and communication systems (Note: subdivision (b) was not added until LL 16/1987. Subdivision (a) may have been intended)

2 Fire Protection Plan - A report containing a narrative description of the life and fire safety systems and evacuation system for a structure. 
- $\quad$ 26-1800.8(c)(2) - Elcvators in readincss

- C26-1801.4 - Locks on elevator hoistway doors

- C26-1801.5 - Fircmcn's scrvice operation for elevators

\subsubsection{Definitions}

LL 16/1984 added several new definitions to sub-article 201.0 of the BCNYC, including the dcfinition of atrium, elevator vestibule, existing building, existing high-rise building, firc protcction plan, fire safcty plan, high rise, low rise, mali, public areas and smoke barrier (LL 16/1984, secs. 13 through 21).

Of particular importance was the addition of the term high rise buildings dcfincd as a structure $75 \mathrm{ft}$ or more in height. All new buildings after the effective date of LL 16/1984 (March 27, 1984) that are $75 \mathrm{ft}$ or more in height are classified as high-rise buildings.

The term existing high rise building was also added and defined to include only high-rise structures: (1) which on April 1, 1984, is complete or under construction, or (2) for which an application for approval of plans has been filed with the department prior to October 1, 1984, and construction commenced prior to April 1, 1986.

WTC 1 and WTC 2 were considered existing high-rise buildings for the purposes of complying with LL 16/1984 and must comply with the provisions for existing high-rise buildings.

WTC 7 was not complete on April 4, 1984; however, it may be considered an existing high-rise building if it complied with condition number 2.

\subsubsection{Height and Area Limitations}

Tables 4-1 and 4-2 of the Building Code were amended to reflect modifications to height and area limitations for unsprinklered and sprinklered buildings and spaces, respectively (LL 16/1984, sec. 23).

\subsubsection{Compartmentation}

Section C26-504.1(c), as added by LL 5/1973, was amended to omit the requirement for compartmentation in new buildings in occupancy group E, $100 \mathrm{ft}$ or more in height, since such buildings will be required to be sprinklered by requirements added by sec. 64 of LL 16/1984. Therefore, compartmentation requirements will only be applicable in existing office buildings $100 \mathrm{ft}$ or more in height.

\subsubsection{Floor Coverings}

Section 26-504.13 was amended by adding a new subdivision (d) for requirements for floor coverings in new construction and alterations of existing buildings (LL 16/1984, sec. 32). 


\subsubsection{Smoke Protection for Elevators and Escalators}

Section 26-504.16(a) was added requiring elevator vestibules for all passenger elevators in existing buildings classified in occupancy group $\mathrm{J}-1$ (hotels), at every floor above the main entrance floor, with exceptions where automatic sprinklers and/or smoke detection systems are provided (LL 16/1984, sec. 33).

Section C26-504.16(b) was added requiring fire protection for escalators in new and existing buildings classified in occupancy group J-1 (LL 16/1984, sec. 33).

\subsubsection{Means of Egress}

Several sections regarding means of egress were amended by LL 16/1984. Most new and amended requirements only pertain to new buildings and alterations to existing buildings. Few sections have been amended requiring compliance retroactively in existing buildings.

An example of a requirement that was applicable to new buildings and alterations of existing buildings is sec. C26-602.3, which was amended to require exits from a floor of a building to be placed as remote as practicable. The minimum distance between exit door openings in all buildings, except oecupancy groups $\mathrm{G}$ and $\mathrm{J}-2$, shall be $30 \mathrm{ft}$ or be one-third the maximum travel distance of the floor, whichever is greater (LL 16/1984, sec. 35).

Retroactive requirements for existing buildings include the following sections:

- C26-605.1(e) - amended to require new and existing buildings containing an F-4 (eating and drinking) place of assembly with an occupant load of 300 or more persons to install emergency lighting in each vertical exit serving the floor on which the place of assembly is located so as to provide a continuously lighted passage to the exterior of the building. The lighting is required to be connected to an emergency power source or to storage battery equipment meeting the requirements of the bureau of electrical control. Owners of existing buildings were required to install the emergency lighting on or before April 1, 1987 (LL 16/1984, sec. 44).

- C26-605.2 - amended to require all new buildings, existing high-rise buildings in occupancy group $\mathrm{C}, \mathrm{D}$ or $\mathrm{H}$, and existing buildings in occupancy group $\mathrm{E}, \mathrm{G}$ or $\mathrm{J}-1$ to connect exit lighting to an emergency power source or storage battery equipment on or before April 1, 1987 (LL 16/1984, sec. 45).

- C26-606.2 - amended to require all new buildings, existing high-rise buildings in occupancy group $\mathrm{C}, \mathrm{D}$ or $\mathrm{H}$, and existing buildings in occupancy group $\mathrm{E}, \mathrm{G}$ or $\mathrm{J}-1$ to connect exit and/or directional exit signs to an emergency power source or storage battery equipment on or before April 1, 1987 (LL 16/1984, sec. 46).

- C26-608.1 and C26-608.7 - amended to require all existing buildings which have at least one elevator to provide stair and elevator signs on or before October 1, 1985 (LL 16/1984, sec. 48 and 49). 
- Sub-article 609.0 Signs in Sleeping Rooms (secs. C26-609.1 through C26-609.3) - addcd to require new and existing buildings in occupancy group $\mathrm{J}-1$ to post and maintain a location sign and diagram on the inside of every door opening onto a public corridor on or beforc April 1, 1987 (LL 16/1984, sec. 50).

\subsubsection{Emergency Power System}

Sub-article 610.0 Emcrgency Power (secs. C26-610.1 through C26-610.3) was added to require owners of certain buildings, including high-rise buildings and building sections classified in occupancy group $\mathrm{C}, \mathrm{E}$, $\mathrm{G}$, and $\mathrm{H}$, to provide an emergency power system. This requirement was applicable to new buildings and certain alterations to cxisting buildings, but not retroactively applicable to existing buildings (LL 16/1984, sec. 50).

\subsubsection{Atriums}

Sub-Article 720.0 (secs. C26-720.1 through C26-720.9) was added to provide requirements for the construction, alteration and use of atriums (LL 16/1984, sec. 52).

\subsubsection{Malls}

Sub-Article 721.0 (sec. C26-721.1 through C26-721.7) was added to provide requirements for the construction, alteration and use of malls (LL 16/1984, sec. 52).

\subsubsection{Smoke Control Requirements}

Section C26-1300.8(a) was added to require owners of new buildings in most occupancy groups, including group $\mathrm{E}$, to have separate ventilation systems supplying different occupancies, corridors, means of egress and other spaces (LL 16/1984, sec. 53).

Section C26-1300.8(b) was added to require buildings in most occupancy groups, including group E, to provide a mechanical system with sufficient capacity to exhaust six air changes per hour or $1 \mathrm{cfm} / \mathrm{ft}^{2}$, whichever is greater, from the largest floor in the building. Such system may be either by dedicated fan equipment or the building ventilation system arranged to shut down automatically with manual override capability to exhaust one floor at a time through a roof or an approved location on an exterior wall (LL 16/1984, sec. 53).

Section C26-1300.9, Ventilation in Existing J-1 Buildings, was added to require owners of existing buildings in occupancy group $\mathrm{J}-1$, either $75 \mathrm{ft}$ or more in height or containing 30 or more sleeping rooms, to separate corridor ventilation from sleeping rooms and to provide manual smoke purging for all corridors and other public areas not provided with natural ventilation (LL 16/1984, sec. 53). 


\subsubsection{Automatic Sprinklers}

Several sections were amended by LL 16/1984 requiring automatic sprinklers in various occupancy groups. New requirements for sprinklers were added for new high-rise buildings and spaces in occupancy groups $\mathrm{E}, \mathrm{F}, \mathrm{G}$, and $\mathrm{J}-1$ and certain low rise buildings in occupancy groups $\mathrm{E}$ and $\mathrm{J}-1$. Sprinklers are also required in certain existing buildings and spaces in occupancy groups $\mathrm{C}, \mathrm{F}$, and $\mathrm{J}-1$.

The requirements for buildings in occupancy group $\mathrm{E}$ are as follows:

- Section C26-1703.1(z) was added to require automatic sprinklers in new high-rise buildings classified in occupancy group $\mathrm{E}$ and low-rise buildings classified in occupancy group $\mathrm{E}$ with a total gross floor area of $100,000 \mathrm{ft}^{2}$ or more.

- Section C26-1703.9(h) was amended to permit standpipe risers to be used to supply water to sprinklers in high-rise buildings classified in occupancy groups $\mathrm{E}, \mathrm{G}, \mathrm{H}$, and $\mathrm{J}$ and in existing office buildings, $100 \mathrm{ft}$ or more in height.

\subsubsection{Fire Alarm and Communication Systems}

Section C26-1704.5 was amended by adding two new subdivisions (i) and (j) requiring fire alarm and communication systems and command stations for new high-rise buildings in occupancy groups $\mathrm{C}$ (mercantile), new and existing high-rise buildings in occupancy group J-1 (hotels) and new and existing low rise buildings in occupancy group J-1 with 30 or more sleeping rooms (LL 16/1984, sec. 75).

Section C26-1704.6(a)(2) was amended to require all fire alarm manual stations installed or relocated after April 1, 1984, to be installed so that the handle is approximately $4 \mathrm{ft}$ from the floor (LL 16/1984, sec. 76).

Section C26-1704.8 as added by LL 5/1973 was amended to modify the requirement for communication systems and fire command stations in buildings in occupancy group E. Local Law 5/1973 initially required such systems in new and existing buildings in occupancy group $\mathrm{E}$ (offices), $100 \mathrm{ft}$ or more in height. Local Law 16/1984 amended this section to require communication systems and fire command stations in new buildings in occupancy group E, $75 \mathrm{ft}$ or more in height, or if less than $75 \mathrm{ft}$ in height, buildings with a total gross area of $200,000 \mathrm{ft}^{2}$ or more. The requirement for existing office buildings remained as $100 \mathrm{ft}$ or more in height (LL 16/1984, sec. 77).

Section C26-1705.2 as added by LL 62/1981 was amended by adding a new subdivision (b) requiring approved and operational smoke detecting devices to be installed in mechanical rooms, electrical switch gear rooms and electric and telephone closets over $75 \mathrm{ft}^{2}$ in gross floor area in all buildings in all occupancy groups (LL 16/1984, sec. 78).

\subsubsection{Elevators}

Section C26-1800.8, as amended by LL 5/1973 and LL 86/1979, was amended to reduce the height of new buildings required to comply with the requirements of elevator in readiness from $100 \mathrm{ft}$ to $75 \mathrm{ft}$, consistent with the new definition of high-rise buildings. This section was also amended to expand on the types of buildings required to comply with this section to include: high-rise buildings classified in 
occupancy groups A, B, C, D, E, F, G, and H, buildings classificd in occupancy group E with a gross arca of $200,000 \mathrm{ft}^{2}$ or more, buildings classificd in occupancy groups $J-1$ and $J-2$, cxisting high-risc buildings classified in occupancy groups C, F, G, and H, existing buildings classificd in occupancy group J-1 and existing office buildings $100 \mathrm{ft}$ or more in hcight (LL 16/1984, scc. 79).

Section C26-1801.4 was added requiring owncrs of existing high-rise buildings to remove any switch, lock or other device on any elevator car or elevator hoistway door that prevents the opening of such doors by anyone not having a key. Existing high-rise buildings werc required to comply with this scction on or before April I, 1987 (LL 16/1984, sec. 80).

Section C26-1801.5 was added to require firemen service opcration (as defincd in ASME A17.1) in existing elevators in high-rise buildings in occupancy group $\mathrm{C}$ and all buildings classified in occupancy group F, G, H, or J-1 on or before April 1, 1987 (LL 16/1984, sec. 80).

\subsubsection{Reference Standards}

In addition to amending existing building codc requirements or enacting new code requirements,

LL 16/1984 also modified existing Reference Standards and added new Refcrence Standards as follows:

- $\quad$ RS 5-19, Standard Mcthod of Fire Tests of Through-Penetration Fire Stops, ASTM International (ASTM) E 814 - 1981 (added LL 16/1984, sec. 85).

- $\quad$ RS 5-20, Standard for the Flammability of Carpets (added LL 16/1984, sec. 85).

- Methane Pill Test, DOC FF1-1970

- Standard Test Method for Critical Radiant Flux of Floor Covering Systems Using a Radiant Heat Source, ASTM E 648-1978

- Standard Test Method for Specific Optical Density of Smoke Generated by Solid Materials, ASTM E 662-1979

- RS 13-1, Standard for the Installation of Air Conditioning and Ventilating Systems, NFPA 90A - 1981, as modified (repealed and re-enacted by LL 16/1984, sec. 87).

- RS 17-3, Standards for the Installation of Fire, Sprinkler, Standpipe, Smoke Detection... and other Alarm and Extinguishing Systems (amended LL 16/1984, secs. 88 through 92).

- RS 17-3A, Standards for the Installation of Class E Fire Alarm Signal Systems (amended LL 16/1984, secs. 93 through 96).

- RS 17-3C, Standard for the Installation of Fire Alarm Signal Systems and Communication Systems for High-Rise Buildings in Occupancy Group C - Mercantile, and J-1 - Residential (Transient), and Buildings in Occupancy Group J-1 - Residential Containing 30 or More Sleeping Rooms (added LL 16/1984, sec. 97). 
- RS 17-3D, Standard for the Installation of Fire Alarm Signal Systems and Communication Systems for Existing Buildings in Either Group J-1 - Residential (Transient) $75 \mathrm{ft}$ or More in Height or with 30 or More Sleeping Rooms (added LL 16/1984, sec. 97).

- $\quad$ RS 18-1, Rule 211.3a (1)(b) (repealed and re-enacted LL 16/1984, sec. 98).

LL 16/1984 was approved by the Mayor on March 27, 1984, and took effect immediately, except as otherwise specifically provided. Note that some of the provisions of LL 16/1984 were further amended by Local Law No. 16 for the year 1987 (LL 16/1987).

\subsection{5 - LAWS OF NEW YORK STATE, RENUMBERING OF NEW YORK CITY ADMINISTRATIVE CODE}

The New York City Administrative Code was renumbered and changed by chapter 907 of the New York State Laws of 1985 and chapter 839 of the New York State Laws of 1986, effective September 1, 1986. The renumbering of the Administrative Code included the Building Code and the Fire Prevention Code of the City of New York.

The Building Code was originally part of Title ' $\mathrm{C}$ ' of Chapter 26 (C26-) of the Administrative Code. After 1985, the General Provisions of the Department of Buildings were organized under Chapter 1 of Title 26 - Housing and Buildings and the Building Code is Chapter 1 of Title 27 - Construction and Maintenance. The format of the Department of Buildings provisions and the Building Code under the renumbered Administrative Code is as follows:

- Title 26- Housing and Buildings

- Chapter 1 - Department of Buildings

- Subchapter 1 - General Provisions

- Subchapter 2 - Licenses

- Subchapter 3 - Building Construction

- Title 27 - Construction and Maintenance

- Chapter 1 - Building Code

- Subchapters 1 through 19

- Appendix - Building Code Reference Standards

Subsequent publications of the BCNYC include the new section number with the former Building Code sections enclosed by parentheses. Conversion or Distribution Tables are also provided in the BCNYC for convenience of converting from former code sections to new code sections and vice-versa. 
The Fire Prevention Code was originally part of Chapter 19 (C19-) of the Administrative Code. After 1985, the Fire Prevention Code was organized under Chapter 4 of Title 27 of the Administrative Code as follows:

- Title 27 - Construetion and Maintenance

- Chapter 4 - Fire Prevention Code

- Subehapters 1 through 29

\subsection{7 - LOCAL LAW NO. 16, FIRE ALARM SYSTEMS AND REFERENCE STANDARDS}

Local Law No. 16 for the year 1987 (LL 16/1987) was approved "To amend the administrative eode of the eity of New York, in relation to fire alarm systems and to repeal reference standards RS 17-3C and RS 17-3D of the appendix thereto." LL 16/1987 made several modifieations to the fire alarm and signal system requirements that were added to the BCNYC by LL 5/1973 and LL 16/1984.

The following is a summary of the sections amended or added by LL 16/1987:

- 27-929 (formerly C26-1700.7) Retroaetive Requirements - amended by adding a new subdivision (b) to revise the dates for compliance with the retroactive provisions of LL 16/1984 for the installation of a fire alarm and signal system in oecupaney group J-1 (hotels). The date for eompleted installation was extended from April 1, 1987 to Deeember 31, 1987 (LL 16/1987, see. 1).

- 27-971(g) (formerly C26-1704.4(g)) Class E system and 27-971(h) (formerly C26-1704.4(h)) Modified Class E system - amended to include the provision of see. 27-973(a)(2) requiring fire alarm stations installed or reloeated after April 1, 1984, to be installed so that the handle is approximately $4 \mathrm{ft}$ from the floor (LL 16/1987, sec. 2).

- 27-971 (formerly C26-1704) was amended by adding four new subdivisions i, j, k, and 1 as follows (LL 16/1987, see. 3):

- (i) Class C fire alarm and eommunieation system - for new mereantile (retail) buildings in oeeupancy group $\mathrm{C}, 75 \mathrm{ft}$ or more in height.

- (j) Class J fire alarm and eommunieation system - for new buildings in oeeupaney group $\mathrm{J}-1$ (hotels), $75 \mathrm{ft}$ or more in height or eontaining 30 or more sleeping rooms.

- (k) Modified class J fire alarm and eommunieation system - for existing buildings in oeeupaney group J-1 (hotels) $75 \mathrm{ft}$ or more in height.

- (1) Modified elass J-1 fire alarm and eommunieation system - for existing buildings in oceupancy group J-1 (hotels) less than $75 \mathrm{ft}$ in height or eontaining 30 or more sleeping rooms. 
- 27-972(i) (formerly C26-1704.5(i) as added by LL 16/1984) was amended to separate the requirements for high-rise buildings classified in occupancy group $\mathrm{C}$ from the requirements for buildings classified in occupancy group J-1 by proving two separate paragraphs (1) and (2) respectively and provide the following modifications (LL 16/1987, sec. 4):

- Paragraph (1) - the Reference Standard for Class C fire alarm systems was changed to RS 17-3A (from RS 17-3C).

- Paragraph (2) - the Reference Standard for Class J-1 fire alarm systems was changed to RS 17-3A (from RS 17-3C). Also, new alternative methods for two-way voice communication systems in lieu of fire warden stations wcre added.

- 27-972(j) (formerly C26-1704.5(i) as added by LL 16/1984) for existing buildings classified in occupancy group $\mathrm{J}-1$, was amended to include two new paragraphs as follows (LL 16/1987, sec. 4):

- Paragraph (1) for existing buildings in occupancy group J-1, $75 \mathrm{ft}$ or more in height provides an exception for "residential hotels" as defined in the Building Department Rules of the City of New York. The Reference Standard for modified Class J fire alarm systems was changed to RS 17-3B (from RS 17-3D). Also, two new alternative methods for two-way voice communication systems in lieu of fire warden stations were added.

- Paragraph (2) was added to provide a new fire alarm system classification, a modified Class J-1 fire alarm and communication system, for existing buildings in occupancy group J-1, less than $75 \mathrm{ft}$ in height and containing thirty or more sleeping rooms. The requirements for a fire command station, public address system and central station monitoring of the fire alarm system are also provided.

- 27-972(k) (formerly C26-1704.5(k)) was added requiring buildings classified in occupancy group C (mercantile), $75 \mathrm{ft}$ or more in height to be provided with a Class $\mathrm{C}$ fire alarm and communications system, including the applicable criteria (LL 16/1987, sec. 5).

- 27-972(1) (formerly C26-1704.5(1)) was added requiring buildings in occupancy group J-1 (hotels), $75 \mathrm{ft}$ or more in height or containing 30 or more sleeping rooms, to be provided with a Class J fire alarm and communication system, including the applicable criteria (LL 16/1987, sec. 5).

- 27-972(m) (formerly C26-1704.5(m)) was added requiring existing buildings in occupancy group J-1 (hotels), $75 \mathrm{ft}$ or more in height or containing 30 or more sleeping rooms, to be provided with a modified Class $\mathbf{J}$ fire alarm and communication system, including the applicable criteria (LL 16/1987, sec. 5).

- RS 17-3A (as added by LL 5/1973) - the title was amended to read "Standards for the Installation of Class E, Class C and Class J Fire Alarm Signal Systems" (LL 16/1987, sec. 6). 
- RS 17-3B (as added by LL 5/1973) - the title was amcnded to rcad "Standards for the Installation of Modified Class E, and Modificd Class J Firc Alarm Signal Systems" (LL 16/1987, sec. 7).

- $\quad$ RS 17-3C (as added by LL 16/1984) was repcaled. The installation standards for firc alarm signal systems and communication systems in high-rise buildings in oecupancy group C - Mercantilc, and J-1 - Residential (transicnt), and buildings in occupaney group J-1 - Rcsidential containing 30 or more slceping rooms is now RS 17-3A (LL 16/1987, sec. 8).

- RS 17-3D (as added by LL 16/1984) was repealcd. The installation standard for the installation of fire alarm signal systems and communication systcms for existing buildings in either occupancy group J-1 - Rcsidential (transient) $75 \mathrm{ft}$ or more in hcight or with 30 or more sleeping rooms is now RS 17-3B (LL 16/1987, sec. 8).

LL 16/1987 was approved by the Mayor on April 20, 1987, and was effective immediately. 
This page intentionally left blank. 


\section{Chapter 5 \\ BUILdING Code REFERENCE StANDARDS}

Since 1968, the Reference Standards (RS) of the Building Code of the City of New York have been updated by Local Laws passed by the City Council, Building Code Rules approved by the New York City Board of Standards and Appeals (BSA) until 1991, and by the authority of the Building Commissioner, after 1991. A New York City Reference Standard may adopt a standard developed and published by an outside standards developer (such as the National Fire Protection Association [NFPA]) in whole or in part, and may choose to modify parts to meet local conditions or practices. When such modifications are adopted, the New York City Reference Standard differs from the published standard. The following is a summary of the applicable fire protection or life safety reference standards and effective dates.

\subsection{RS 5-2, ASTM E 119}

RS 5-2, Standard Methods of Fire Tests of Building Construction Materials, ASTM International (ASTM) E $119-1961$

- Added by Local Law No. 76/1968 (LL 76/1968), effective December 6, 1968

- Amended by BSA 217-72-BCR, effective April 25, 1972

- Amended by BSA 1343-88-BCR, effective December 20, 1988

\subsection{RS 5-5, ASTM E 84}

RS 5-5, Standard Method of Test for Surface Burning Characteristics of Building Materials, ASTM E $84-1961$

- Added by LL 76/1968, effective December 6, 1968

- Amended by BSA 218-72-BCR, effective April 25, 1972

- Amended by BSA 308-81-BCR, effective June 16, 1981

- Amended by BSA 1343-88-BCR, effective December 20, 1988

\section{$5.3 \quad$ RS 5-8, NFPA 80}

RS 5-8, Installation of Fire Doors and Windows, NFPA 80 - 1967

- Added by LL 76/1968, effective December 6, 1968

- Amended BSA 71-79-BCR, effective February 20, 1979 
- Amended by BSA 308-81-BCR, effective June 16, 1981

- Amended by BSA 1343-88-BCR, effective December 20, 1988

\section{4} RS 13-1, NFPA 90A

RS 13-1, Standard for the Installation of Air Conditioning and Ventilating Systems, NFPA 90A - 1967, as modified

- $\quad$ Added by LL 76/1968, effective December 6, 1968

- Amended by LL 16/1984, effective March 27, 1984

- Amended by BSA 17-87-BCR, effective February 10, 1987

- Repealed and added by Building Department, effective May 4, 2002

\subsection{RS $17-1$, STANDPIPE CONSTRUCTION}

RS 17-1, Standpipe Construction

- Added by LL 76/1968, effective December 6, 1968

- Amended by BSA 177-72-BCR, effective April 18, 1972

- Amended by LL 5/1973, effective January 18, 1973

- Amended by BSA 1014-0-BCR, effective November 25, 1980

- Amended by BSA 384-82-BCR

- Amended by BSA 310-90-BCR, effective January 22, 1991

- Amended by Building Department, effective July 24, 1996

\subsection{RS 17-2, NFPA 13}

RS 17-2, Standard for the Installation of Sprinkler Systems NFPA 13 - 1966, as modified

- Added by LL 76/1968, effective December 6, 1968

- Amended by BSA 633-83-BCR, effective September 13, 1983

- Amended by BSA 310-90-BCR, effective January 22, 1991

- Amended by Building Department, effective April 3, 2003 


\subsection{RS 17-3, FIRE ALARM AND EXTINGUISHING SYSTEMS}

RS 17-3, Standards for the Installation of Fire, Sprinkler, Standpipc, Smoke Detcetion... and other Alarm and Extinguishing Systems

- Added by LL 76/1968, effectivc December 6, 1968

- Amended by BSA 149-75-BCR, effective May 6, 1975

- Amended by BSA 515-75-BCR, effective Deccmber 2, 1975

- Amended by LL 16/1984, effectivc March 27, 1984

- Amended by Building Department, effective April 3, 2003

\section{8 $\quad$ RS 17-3A, CLASS E FIRE ALARM SYSTEMS}

RS 17-3A, Standards for the Installation of Class E, Class C, and Class J Fire Alarm Signal Systems

- Added by LL 5/1973, effective January 18, 1973

- Amended by LL 16/1984, effective March 27, 1984

- Amended by Building Department, effective April 3, 2003

\subsection{RS 17-3B, MODIFIED CLASS E FIRE ALARM SYSTEMS}

RS 17-3B, Standards for the Installation of Modified Class E, and Modified Class J, Fire Alarm Signal Systems

- $\quad$ Added by LL 5/1973

- Amended by BSA 49-74-BCR, effective March 12, 1974

- Amended by LL 16/1984, effective March 27, 1984

- Amended by LL 16/1987, effective April 20, 1987

- Amended by Building Department, effective April 3, 2003 


\subsection{RS 17-5, NFPA 72}

RS 17-5, Proprietary and Auxiliary Protective Signaling Systems, NFPA 72 - 1967

- Added by LL 76/1968, effective December 6, 1968

- Amended by BSA 310-90-BCR, effective January 22, 1991

- Repealed and added by Building Department, effective January 9, 2002

\subsection{RS 18-1, AMERICAN NATIONAL STANDARDS INSTITUTE A17.1}

RS 18-1, USA Standard Safety Code for Elevators, Dumbwaiters, Escalators, and Moving Walks, USASI 17.1 - 1965, including Supplement A17.1a-1967, as modified

- Added by LL 76/1968, effective December 6, 1968

- Amended by BSA 385-82-BCR, effective August 10, 1982

- Amended by LL 16/1984, effective March 27, 1984

- Amended by BSA 678-85-BCR, effective October 1, 1985

- Amended by BSA 11-91-BCR, effective March 12, 1991

- Amended by Building Department 


\section{Chapter 6}

REFERENCES

City Publishing Center Department of General Services. 1968. The City of New York Building Code.

New York, NY, December 6. 
This page intentionally left blank. 

